\title{
Hybrid rhyolitic eruption at Big Glass Mountain, CA, USA
}

\author{
Jonathan M. Castro*, Sebastian Walter \\ Johannes Gutenberg-Universität Mainz, Mainz, Germany.
}

\begin{abstract}
Eruptive dynamics of the 1060 CE eruption of rhyolite from Big Glass Mountain (BGM), USA, are investigated with field observations, hydrogen isotope, and $\mathrm{H}_{2} \mathrm{O}$ content analysis of pyroclastic obsidian chips and lavas. Field relations at BGM reveal evidence for hybrid eruption, defined as synchronous explosive venting and effusive emplacement of vast obsidian lava flows. This activity is particularly well manifested by extensive breccia zones implanted within the BGM obsidian lavas, which may represent rafted tephra cones, in addition to remnants of airfall tephra on the lava. Rhyolitic obsidians collected from a 2.5-m-thick fall deposit and co-eruptive lava flow were studied by FTIR and TCEA methods to elucidate the eruption's degassing history. The data, along with VolcDeGas program simulations, demonstrate a correlation between $\mathrm{H}_{2} \mathrm{O}$ content and $\mathrm{H}$-isotopic composition $(\delta \mathrm{D})$ reflecting ever-increasing amounts of volatile and deuterium loss to the vapor phase. VolcDeGas simulations suggest a best-fit degassing mechanism comprised of repetitive, variably sized closed-system steps, which is termed "batched degassing". This degassing mechanism, along with the field evidence at BGM, implies an eruptive sequence that is devoid of a sharp break and entirely consistent with observed Chilean rhyolite eruptions: initial explosive venting transitioning to hybrid eruption. Collectively, the $\mathrm{H}_{2} \mathrm{O}-\delta \mathrm{D}$ patterns and field characteristics of BGM eruption deposits lend credence to the idea that hybrid venting is common during rhyolite eruptions and should be accounted for in future eruption hazards assessments.
\end{abstract}

Keywords: Big Glass Mountain; Rhyolite; Obsidian; Pyroclasts; Batched degassing; Hydrogen isotopes; Explosive-effusive eruption;

\section{InTRODUCTION}

Studying silicic volcanism, particularly rhyolite eruptions, is critical to assessing volcanic threat [e.g. Eichelberger 1995; Castro and Dingwell 2009; Watt et al. 2009]. A first-order question in the context of volcanic hazard mitigation is, How will an eruption progress once underway? Early work on Holocene rhyolitesa rare yet physically impactful form of volcanismrecognized that these systems are both "explosive and effusive" in nature, this assessment being drawn from field observations of obsidian lava flows perched atop pyroclastic fall deposits [e.g. Heiken 1978; Eichelberger and Westrich 1981; Taylor et al. 1983]. The lack of preserved tephra on top of the lavas lead to the logical conclusion that the eruptions followed an explosive-toeffusive sequence, with lavas emerging after the explosive eruptions ceased [e.g. Miller 1985; Donnelly-Nolan et al. 2016]. Disparate eruption styles were explained by the different magmatic $\mathrm{H}_{2} \mathrm{O}$ contents in pyroclasts and lavas, which showed that the former still had significant quantities of primary $\mathrm{H}_{2} \mathrm{O}$, while the latter were nearly completely degassed [Eichelberger and Westrich 1981; Taylor et al. 1983]. A uni-directional shift from explosive to effusive behavior, it was argued, depended on how efficiently the magma could degas during ascent, itself a complicated function of intrinsic magma vesicularity and permeability [Eichel-

\footnotetext{
*Corresponding author: castroj@uni-mainz.de
}

berger et al. 1986]. Modeling studies reinforced the notion of bifurcating eruption behavior, even predicting sharp "explosive-to-effusive" transitions as bubbly magma becomes highly permeable, ascent and shearing rates wane, and magma chamber overpressure declines during magma rise [Jaupart and Allègre 1991; Woods and Koyaguchi 1994; Gonnermann and Manga 2003; 2007].

Despite many insightful studies on rhyolites, it came as a surprise then when eruptions in Chile were first observed [Lara 2009; Alfano et al. 2011; Castro et al. 2013; Schipper et al. 2013; Castro et al. 2014], as these events showed that rhyolite eruptions may actually progress differently than previously thought. After initial week-long explosive episodes, eruptions at both Chaitén (2008) and Cordón Caulle (2011), Chile, exhibited rarely seen "hybrid" activity, comprising simultaneous pyroclastic fountains (100s to 1000s m) and lava eruptions from the same vents [Schipper et al. 2013; Castro et al. 2014; 2016]. Such activity had only once been reported on once before in regards to 1960 rhyodacitic fissure eruption at Cordón Caulle [e.g. Katsui and Katz 1967; Lara et al. 2004]. The eruptions concluded with purely effusive activity [Pallister et al. 2013; Tuffen et al. 2013].

The hybrid eruption phases, which were the most protracted (i.e. months-long) and lasted until a majority of the lava fields were emplaced, started with lava emerging directly from one or more tephra cones [e.g. 
Castro et al. 2014; 2016]. The lavas occasionally bulldozed these fragmental edifices, causing the pyroclastic deposits to be rafted away by the flows [Pallister et al. 2013; Schipper et al. 2013, Supplementary Material]. The result of such effusive and explosive coeruption can be readily seen in the mixing of breccia, or tephra ridges within the lava fields at both Chaitén and Cordón Caulle [Figure 1; Tuffen et al. 2013; Castro et al. 2014].

A particularly important question is, Just how common was hybrid activity in the many pre-historic (late Holocene) obsidian producing events? Evidence for long-lasting hybrid ash and lava venting at other well studied pre-historic rhyolite systems has begun to emerge. Black et al. [2016] discovered pyroclastic degassing structures, so-called tuffisites, on Panum Dome rhyolite (CA) that they interpret as evidence of explosive ash venting during the emplacement of an obsidian dome. Black et al. [2016] conclude that persistent ash venting would be a significant threat to air traffic, thereby underscoring the importance of studying prehistoric rhyolites in order to clarify how these systems may have erupted in the past, and how they may possibly erupt in the future.

In order to improve our understanding of how prehistorical rhyolites may have erupted, we have investigated field and geochemical characteristics of the 1060 CE eruption of Big Glass Mountain, CA, USA (BGM) [e.g. Anderson 1933; Chesterman 1955; DonnellyNolan et al. 2007; 2008]. This explosive and effusive event produced about $0.1 \mathrm{~km}^{3}$ of rhyolitic tephra and the most voluminous rhyolitic obsidian flow $\left(\sim 1 \mathrm{~km}^{3}\right)$ in Cascades volcanic province [Heiken 1978]. Existing literature purports that the effusive phase of BGM began after explosions had ceased [e.g. Donnelly-Nolan et al. 2016]. However, as we show, BGM erupted simultaneously in explosive and effusive modes, this evidenced by physical depositional features and by hydrous geochemical trends in deposits that are strikingly similar to features observed in previously monitored Chilean eruptions [e.g. Lara 2009; Castro et al. 2013]. Our data show that hybrid explosive-effusive activity was important during Big Glass Mountain's most recent eruption and such eruptive activity may be more common than previously recognized.

\section{BACKGROUND}

In this section we review important aspects of the Big Glass Mountain eruption, including its salient deposit characteristics and hydrous geochemical patterns thereof that served as the earliest basis for models of explosive-effusive rhyolite eruptions. We then summarize the hydrous geochemical patterns observed in pyroclastic and effusive deposits of different pre-historic (including BGM) and recently active rhyolite systems, and convey how these published data have shaped the- ories of how rhyolite magma degasses during explosive and effusive eruption modes.

Big Glass Mountain is a late-Holocene dacitic to rhyolitic volcanic complex located near the summit of Medicine Lake Volcano (MLV), northern California [e.g. Donnelly-Nolan et al. 2008]. The latest activity of MLV, about 950 years ago [Donnelly-Nolan et al. 2007], formed Big Glass Mountain, a broad ( $\sim \mathrm{km}$ diameter) silicic landform comprising pyroclastic fall deposits, near-vent breccia and tephra cones, and a voluminous obsidian flow. Although some andesitic material is found in the most recent BGM eruption deposits, and is probably co-eruptive, the majority of the complex ranges from dacite to rhyolite in composition [Donnelly-Nolan et al. 2016]. The youngest eruption deposits, originating from a $\sim 6 \mathrm{~km}$ NW-SE trending fissure, comprise some $0.1 \mathrm{~km}^{3}$ rhyolitic tephra and $\sim 1$ $\mathrm{km}^{3}$ of rhyodacite to rhyolite obsidian lava flows and domes [Heiken 1978; Donnelly-Nolan et al. 2016]. Numerous studies have elucidated the general progression of the eruption, including its trigger via magma injection [Eichelberger 1975] and ensuing eruptive activity, which presumably began with early pyroclastic venting followed by late-stage effusion of compositionally mixed silicic lava [e.g. Heiken 1978; Eichelberger and Westrich 1981]. Heiken [1978] suggested that the volumetric dominance of lava over tephra ( 9:1 at BGM), is characteristic of moderate-volume rhyolite eruptions, including the Little Glass Mountain complex on MLV, the Inyo Domes [Heiken 1978; Castro and Gardner 2008], and the Rock Mesa and Devils Hill rhyolites on South Sister Volcano, Oregon [e.g. Scott 1987].

The pyroclastic and effusive deposits at BGM contain abundant rhyolitic obsidian (Figure 1); these glasses were some of the first ever to be analyzed to constrain volatile contents in rhyolite magmas. In their landmark study, Eichelberger and Westrich [1981] demonstrated that BGM (and Little Glass Mountain) obsidians contain a range of remnant (0.1 to $\sim 1.0 \mathrm{wt} . \%)$ magmatic $\mathrm{H}_{2} \mathrm{O}$ (and minor $\mathrm{CO}_{2}$ ). This $\mathrm{H}_{2} \mathrm{O}$ range reflects values measured on effusive (the minimum values) and pyroclastic obsidians (upper range in $\mathrm{H}_{2} \mathrm{O}$ ). Eichelberger and Westrich [1981] interpreted this water to be the primary driver for explosive rhyolite eruptions at Medicine Lake. Their measurements also showed that obsidian lavas are nearly completely depleted in $\mathrm{H}_{2} \mathrm{O}(\sim 0.1 \mathrm{wt} . \%)$, which-together with the relatively more hydrous pyroclast data-suggested that the magma body feeding explosive and effusive eruptions was stratified in $\mathrm{H}_{2} \mathrm{O}$. Thus, the primary implication was that eruption style is dictated by how much $\mathrm{H}_{2} \mathrm{O}$ is in the magma, with the explosive-to-effusive transition being triggered by $\mathrm{H}_{2} \mathrm{O}$-rich magma being exhausted and positioned "abruptly" atop drier magma that would later erupt effusively.

In addition to the absolute $\mathrm{H}_{2} \mathrm{O}$ contents of eruption products, the $\mathrm{H}$-isotopic signatures of pyroclastic and effusive obsidians at Medicine Lake and other Holocene 

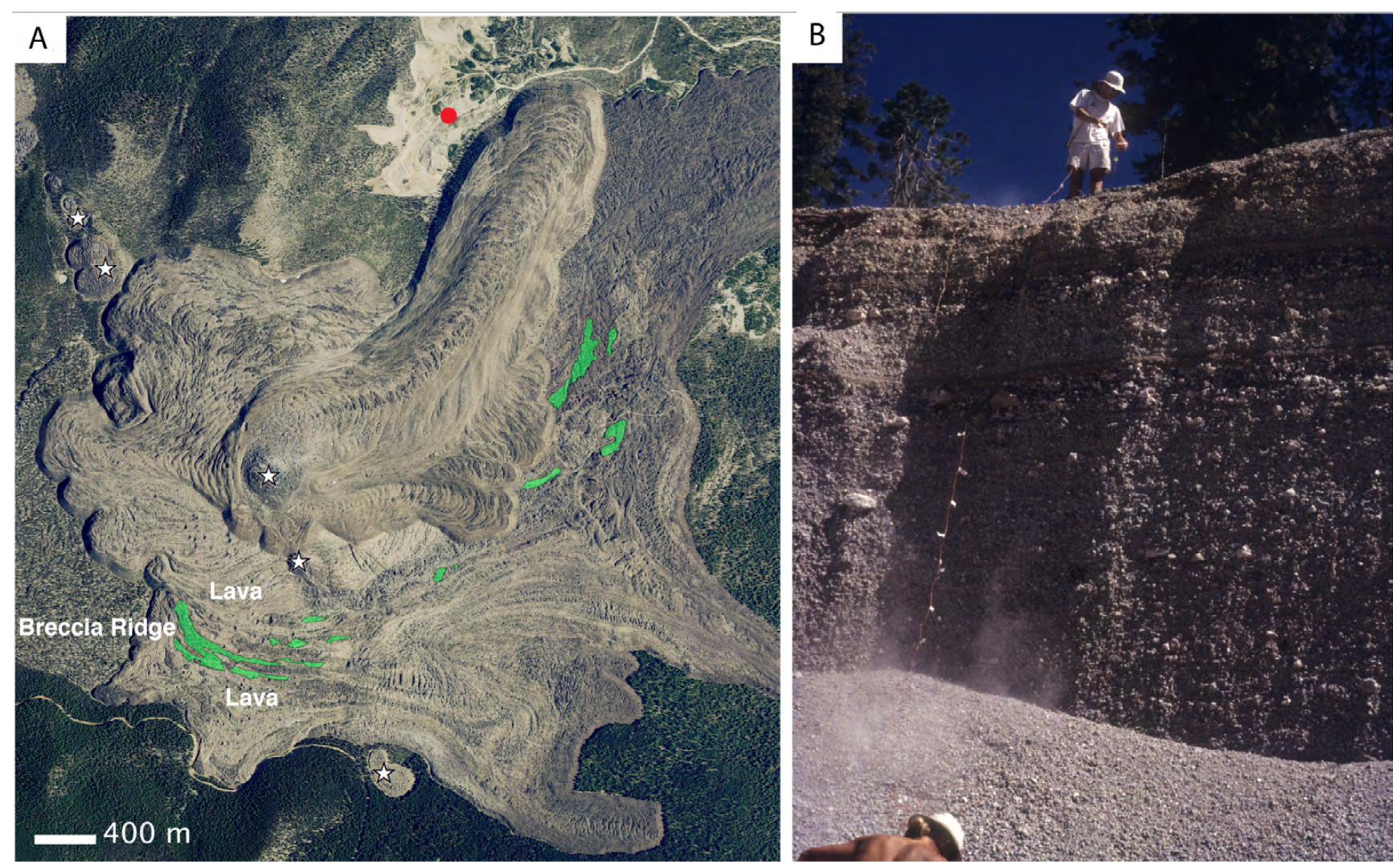

Figure 1: [A] Satellite image of Big Glass Mountain (BGM), northern California. North direction is up in image. Imagery dates from 29 June 2017 and is provided by the National Agricultural Imagery Program (NAIP/USDAFSA). Obsidian lava of BGM occupies most of the field of view, however co-eruptive air-fall deposits are apparent in vegetated land and in the quarry to the NW of the BGM flow. White stars show the approximate locations of vents within the flow and on the extension of the presumed fissure system [e.g. Eichelberger 1975]. The red dot shows the approximate location of our pyroclastic samples, collected in 1997. Green areas superimposed on the flow demarcate breccia ridges, which host significantly more vegetation than the normal flow top lava. Breccia ridges are particularly well exposed and positioned inboard of the southern and westernmost flow fronts, indicating that they were incorporated into the flow at some point after the onset of effusive activity [B] Close-up view of the $\sim 2.5$-m-tall outcrop of pumice and obsidian fall. We sampled this section at $15 \mathrm{~cm}$ intervals (shown by white tape markings on section line). Mapping by Chesterman [1955] suggests the total fallout section thickness is $3.6 \mathrm{~m}$ at this location.

systems (e.g. Inyo Domes and Mono Craters, CA) have been used to elucidate specific degassing mechanisms responsible for syn-eruptive gas release [e.g. Taylor et al. 1983; Newman et al. 1988; Dobson et al. 1989; Rust et al. 2004]. As studies have shown, hydrogen isotopic measurements on pyroclastic and effusive obsidians trace relatively consistent patterns of initial subtle decline in $\delta \mathrm{D}$ in relatively hydrous pyroclasts (e.g. from $\sim 4$ to $1 \mathrm{wt} . \% \mathrm{H}_{2} \mathrm{O}$ [Newman et al. 1988]), and later extreme isotopic fractionation (i.e. deuterium depletion) comprising a sharp exponential decrease in $\delta \mathrm{D}$ for the last several tenths of a wt.\% of $\mathrm{H}_{2} \mathrm{O}$ found in obsidian lavas. These trends have been interpreted as evidence for initial "closed-system" degassing related to explosive processes (i.e. corresponding to hydrous pyroclasts [Taylor et al. 1983]), and later "open-system" degassing in obsidian-flow producing phases. Eichelberger et al. [1986] purport that the open-system signatures of ob- sidian lavas reflect the inevitable transition of rising bubbly magma to a highly permeable state, which in turn induces effective and immediate gas-melt separation that will result in dry magma capable of erupting "quiescently" [Eichelberger et al. 1986].

Most recently, Giachetti et al. [2020] performed detailed hydrous geochemical $\left(\mathrm{H}_{2} \mathrm{O}\right.$ and $\left.\delta \mathrm{D}\right)$ and paired porosity measurements of pyroclastic and effusive obsidians and pumices from Big Glass Mountain's 1060 CE eruption. Similar to previous interpretations [e.g. Eichelberger et al. 1986; Newman et al. 1988], this study contends that the BGM eruption progressed from early closed to open-system degassing, the shift being caused by bubbly magma reaching a threshold $\sim 65 \%$ porosity. Like the Eichelberger et al. [1986] model, the main mechanism bringing about this changes is magma reaching a permeability threshold, beyond which opensystem degassing takes over and quiescent effusion oc- 
curs.

In contrast to the aforementioned studies that treat rhyolite eruptions as two-stage, closed-to-open systems Taylor [1991] proposed "batched degassing", a multi-stage, repetitive degassing mechanism for late-Holocene explosive-effusive rhyolite eruptions at the Inyo Domes, CA [Miller 1985]. According to this model-termed "multi-step open/closed"hydrous magma outgasses in repetitive closed-system "batches" that are periodically released by explosions that vent exsolved gas to the surface. The repetitive closed system batches may get progressively smaller with time as the hydrous magmatic component declines with successive eruptions. The net effect of Taylor's [1991] model is the progressive depletion of the magma's $\mathrm{H}_{2} \mathrm{O}$ budget, which enhances "quasi-open" system behavior with each degassing step.

Taylor's multi-step model fit to the Inyo Domes isotopic data yields isotopic shifts and $\delta \mathrm{D}-\mathrm{H}_{2} \mathrm{O}$ trends that are excellent fits to both the initial subtle decrease in pyroclastic obsidian $\delta \mathrm{D}$, and the later extreme deuterium depletion observed in lavas. The repetitive nature of the degassing process, Taylor [1991] contends, is manifested in the physical character of pyroclastic deposits themselves, which exhibit stratified heterogeneous distributions of obsidian- and pumice-rich layers (Figure 1). Although not explicitly stated in Taylor's [1991] work, the multi-step, batched-degassing model represents a single repetitive mechanism that geochemically links explosive to effusive products. In other words, the model does not entail an abrupt shift in degassing mechanism nor does it require that eruptive activity change as the aforementioned two-stage models do [e.g. Newman et al. 1988; Giachetti et al. 2020].

Castro et al. [2014] applied Taylor's [1991] batcheddegassing approach to model $\delta \mathrm{D}-\mathrm{H}_{2} \mathrm{O}$ measurements on explosive and effusive products from the first scientifically observed rhyolite eruption, that of Chaitén volcano, Chile [Castro and Dingwell 2009; Castro et al. 2012]. Because this event was well monitored, the $\mathrm{H}_{2} \mathrm{O}$ and isotopic measurements and modeling thereof could be directly linked to the observed eruptive behavior. Castro et al. [2014] found that a multi-step, batcheddegassing mechanism could fit the $\delta \mathrm{D}-\mathrm{H}_{2} \mathrm{O}$ data from the entire eruptive complement: early-erupted Plinian pumice and obsidian lapilli, Vulcanian bombs, and lavas. In addition, the multi-step degassing degassing mechanism was entirely consistent with and correlative to the observed eruption behavior, in particular hybrid activity at Chaitén (simultaneous bomb blast and pyroclastic venting alongside effusion) that commenced shortly after the eruption had started.

The simultaneous explosive and effusive eruption of Chaitén involved persistent ash venting and repetitive explosions, much like those seen at Cordón Caulle a few years later [e.g. Castro et al. 2013; Schipper et al. 2013; 2021]. The ubiquitous explosions that occur during effusion [e.g. Schipper et al. 2013] are manifesta- tions of the periodic build up and release of pressure on conduit-spanning fractures and pyroclastic degassing channels known as tuffisites, whose time-dependent porosity and permeability [Black et al. 2016; Saubin et al. 2016; Heap et al. 2019; Schipper et al. 2021] lead to intermittent bomb blast and ash venting activity [Castro et al. 2012; 2014; Black et al. 2016]. Collectively, the eruption observational information, geochemical signatures, and textural features of Chaitén and Cordón Caulle argue for a degassing mechanism that could operate relatively unchanged across the whole eruptive sequence, including initial Plinian explosions and later synchronous, hybrid venting of pyroclasts and lava.

In summary, rhyolitic obsidian eruptions have historically been viewed as "explosive OR effusive", and accordingly ascribed to a two-stage degassing history [e.g. Cabrera et al. 2015]. Indeed, the overwhelmingly dominant interpretation of hydrous geochemical data and physical textures in eruption products is one indicating a sharp "transition" in eruptive style, coinciding with the degassing regime shift from closed to open-system [e.g. Taylor et al. 1983; Eichelberger et al. 1986; Newman et al. 1988; Eichelberger 1995]. Testing whether this interpretation is valid is clearly important for accurately assessing the hazards of these and future events, especially considering that the two observed Chilean rhyolite eruptions did not behave according to current paradigms. In other words, because the hybrid form of activity is temporally dominant (lasting months to more than a year) in the observed events, very different hazards are implied than would be considering the prevailing "explosive OR effusive" paradigm [e.g. Castro et al. 2014; Saubin et al. 2016; Forte 2019; Forte and Castro 2019].

Aside from the work of Castro et al. [2014], no previous study has linked both field and geochemical evidence of degassing to hybrid eruptive activity in a rhyolite system. Thus, our goal is to find hallmarks of this behavior in the geochemical and physical nature of deposits at BGM. Our results show that hybrid activity played a dominant role in the pre-historic rhyolite eruption of BGM.

\section{SAMPLES AND ANALYTICAL METHODS}

\subsection{Sample collection}

We collected tephra samples in September, 1997, from a freshly exposed, $2.5 \mathrm{~m}$-tall vertical outcrop of airfall tephra in a pumice quarry ("Fouch pumice pit" [Chesterman 1955]) on the north side of the Big Glass Mountain obsidian flow (Figure 1). This sample location was selected in part based on field mapping by Heiken [1978], whose own tephra sections and isopach maps reveal a maximum deposit thickness ranging from $\sim 3-6 \mathrm{~m}$ in the quarry we sampled from. The bottom of the air-fall tephra was not encountered 
during our sampling but it could have extended up to $1 \mathrm{~m}$ beneath our lowest sample owing to an earlier published estimated total deposit thickness at this location of about $3.6 \mathrm{~m}$ [Chesterman 1955]. At the time of our sampling, exposures in the quarry could be continuously traced to the contact they made with the northern obsidian flow lobe. This confirmed that the location of our sampling corresponds to a conformable stratigraphic (and co-eruptive) pyroclastic fall linked the overlying effusive lava (Figure 1).

We sectioned pyroclastic samples in bulk with a small trowel at $15 \mathrm{~cm}$ intervals over the entire $2.5 \mathrm{~m}$ exposed section. Samples were placed into air- and watertight bags in amounts of about one kilogram. As talus obscured the base of the fall deposit, it is unclear where the tephra fall section ended. However, the sampled section does represent a majority of the upper part $(\sim 70 \%)$ of the fall deposit at this location (i.e. $2.5 \mathrm{~m}$ of a total $3.6 \mathrm{~m}$ [Chesterman 1955]). Although we cannot establish the relative age of the tephra deposit with respect to the neighboring lava-i.e. if they erupted simultaneously-these pyroclastic samples collected at a high sampling interval (about every $15 \mathrm{~cm}$ ) do contain an important record of the explosive phase at BGM and, in the event that it did temporally overlap with effusive activity, could reveal hydrous geochemical signatures evolve during hybrid activity [e.g. Castro et al. 2014].

The pyroclastic samples analyzed in this study are labeled from deposit top to bottom as 2 a through $15 \mathrm{a}$ and comprise rhyolite pumice, obsidian chips, and grey lithic fragments (Table 1). Because the pumice samples, comprising 1-5 cm sized lapilli fragments, are in all likelihood hydrated by meteoric waters [Eichelberger and Westrich 1981; DeGroat-Nelson et al. 2001; Giachetti et al. 2020], we did not analyze them. We instead focused analyses on obsidian fragments $(\sim 0.5-2 \mathrm{~cm}$ in diameter). We separated 35 glass chips from the bulk pyroclast samples, and set them aside for geochemical analysis. The possibility that these obsidian clasts were hydrated can be discounted on the basis of their relatively young age $\left(\sim 10^{3} \mathrm{yrs}\right)$, low $(<5$ vol.\%) to negligible porosity, and the exceptionally slow rates of glass hydration at surface conditions $\left(\sim 1-10 \mu \mathrm{m} \mathrm{kyr}^{-1}\right.$; e.g. Anovitz et al. [2004]). For example, recent hydration modeling of natural fulgurite glasses shows that significant uptake of meteoric water in dense silicate glass requires thousands to hundreds of thousands of years [Castro et al. 2020]. Based on this evidence, it is unlikely that BGM pyroclastic and effusive obsidians have undergone appreciable hydration since their eruption.

We also collected dense obsidian lava samples from the northeastern and southern lobes of Big Glass Mountain obsidian flow; these samples were also analyzed for their $\mathrm{H}_{2} \mathrm{O}$ contents by FTIR using well established techniques [e.g. Castro et al. 2005b], and were found to be very $\mathrm{H}_{2} \mathrm{O}$ depleted $(\sim 0.13$ wt.\%). However, isotopic (TCEA) analyses (see Section 3.2) of these same samples were problematic in that $\mathrm{H}_{2} \mathrm{O}$ contents were erroneously high, perhaps due to clogging of the reaction chamber in the instrument. Hence isotopic and $\mathrm{H}_{2} \mathrm{O}$ content data of these samples have been discarded in favour of published data on BGM effusive obsidians from DeGroat-Nelson et al. [2001]. The inclusion of these data shall induce no uncertainty stemming from the types or locations of these obsidians because one of the authors of the present study (Castro) assisted in the sampling campaign of DeGroat-Nelson et al. [2001].

\subsection{Analytical techniques}

Measurements of the deuterium $\left({ }^{2} \mathrm{H}\right)$ to hydrogen $\left({ }^{1} \mathrm{H}\right)$ ratio $(=\delta \mathrm{D})$ on 74 pyroclastic obsidian clasts (Table 1 ) were carried out at the Johann Wolfgang GoetheUniversity in Frankfurt using TCEA-MS (Thermal Conversion Element Analyzer-Mass Spectrometer). $\delta \mathrm{D}$ is assessed with respect to Standard Mean Ocean Water (SMOW) and is defined as follows:

$$
\delta \mathrm{D}=\left(\frac{\left(\frac{{ }^{2} \mathrm{H}}{{ }^{1} \mathrm{H}}\right)_{\text {sample }}-\left(\frac{{ }^{2} \mathrm{H}}{{ }^{1} \mathrm{H}}\right)_{\text {standard }}}{\left(\frac{{ }^{2} \mathrm{H}}{{ }^{1} \mathrm{H}}\right)_{\text {standard }}}\right) \times 1000 \% .
$$

Standard glasses (NBS-30, NBS-22, CH7) were measured during the analysis session to verify instrument accuracy.

We followed the sample preparation techniques outlined in Nolan and Bindeman [2013] and Castro et al. [2014], which are briefly summarized here. After selecting fresh $\sim 1-\mathrm{cm}$-diameter obsidian chips for analysis, the materials were cleaned in an ultrasonic bath and individual pyroclasts where then split by breaking them into coarse fragments with a steel mortar and pestle whereupon a large $(\sim 3 \mathrm{~mm})$ fragment was set aside for FTIR analysis. In doing a replicate FTIR measurement on the same material as would be measured by TCEA-MS, we could compare (and independently check) $\mathrm{H}_{2} \mathrm{O}$ content assessments. The remaining fragments of the broken clast were dedicated to TCEA-MS analyses, and thusly, ground in an agate mortar to a grain size of about $150 \mu \mathrm{m}$, constrained by passing the powdered samples through sieves. The powders were then packed into silver cups and folded shut before weighing on an analytical balance with 6 digit precision. The mass of material analyzed $(\sim 3-10 \mathrm{mg})$ was determined in part by the anticipated range of $\mathrm{H}_{2} \mathrm{O}$ in the samples [e.g. Bindeman et al. 2012; Nolan and Bindeman 2013]. The hydrogen isotopic analyses were performed on a Thermo Finnegan TCEA-MAT 253 system, which yields $\delta \mathrm{D}_{\text {SMOW }}=\left(\left[\left({ }^{2} \mathrm{H} /{ }^{1} \mathrm{H}\right)_{\text {sample }} /\left({ }^{2} \mathrm{H} /{ }^{1} \mathrm{H}\right)\right]-1\right) \times 10^{3}$. Measurements have a precision of $\pm 3 \%$ for $\delta \mathrm{D}$. In some cases (e.g. very dry obsidian) more sample material was needed leading to a larger capsule, which in turn had poor positioning within the TCEA reactor cham- 
Table 1: $\delta \mathrm{D}$ and bulk $\mathrm{H}_{2} \mathrm{O}$ content of pyroclastic and effusive obsidians from Big Glass Mountain, CA, USA. S.D. = standard deviation; n.d. = not determined.

\begin{tabular}{|c|c|c|c|c|c|c|}
\hline Sample name & $\begin{array}{c}\text { Type } \\
\text { (position) }\end{array}$ & $\delta \mathrm{D}(\%$ o $)$ & S.D. $(\% o)$ & $\begin{array}{c}\mathrm{H}_{2} \mathrm{O} \text { by } \\
\text { FTIR (wt.\%) }\end{array}$ & $\begin{array}{c}\mathrm{H}_{2} \mathrm{O} \text { molec. } \\
(\text { wt. } \%)\end{array}$ & $\mathrm{OH}($ wt. $\%)$ \\
\hline $\mathrm{Mz}_{-}$VTS0_2a3 $(n=2)$ & Pyroclastic $(30 \mathrm{~cm})$ & -104.6 & 1.6 & 0.40 & 0.10 & 0.30 \\
\hline Mz_VTS0_2a4 $(n=2)$ & Pyroclastic $(30 \mathrm{~cm})$ & -90.7 & 3.0 & 0.76 & 0.14 & 0.63 \\
\hline Mz_VTS0_2a5 $(n=2)$ & Pyroclastic $(30 \mathrm{~cm})$ & -99.3 & 0.5 & 0.57 & 0.09 & 0.49 \\
\hline Mz_VTS0_2b1 $(n=2)$ & Pyroclastic $(45 \mathrm{~cm})$ & -92.5 & 1.0 & 0.79 & 0.16 & 0.64 \\
\hline Mz_VTS0_2b2 $(n=2)$ & Pyroclastic $(45 \mathrm{~cm})$ & -95.0 & 0.2 & 0.75 & 0.14 & 0.61 \\
\hline Mz_VTS0_2b4 $(n=2)$ & Pyroclastic $(45 \mathrm{~cm})$ & -95.7 & 1.2 & 0.52 & 0.08 & 0.45 \\
\hline Mz_VTS0_3a2 $(n=2)$ & Pyroclastic $(60 \mathrm{~cm})$ & -115.4 & 1.7 & 0.24 & 0.03 & 0.21 \\
\hline Mz_VTS0_3a3 $(n=2)$ & Pyroclastic $(60 \mathrm{~cm})$ & -90.9 & 1.9 & 0.74 & 0.10 & 0.64 \\
\hline Mz_VTS0_3a4 $(n=2)$ & Pyroclastic $(60 \mathrm{~cm})$ & -100.4 & 5.0 & 0.53 & 0.12 & 0.41 \\
\hline Mz_VTS0_3b3 $(n=2)$ & Pyroclastic $(75 \mathrm{~cm})$ & -90.2 & 2.2 & 0.80 & 0.17 & 0.63 \\
\hline Mz_VTS0_3b4 $(n=2)$ & Pyroclastic $(75 \mathrm{~cm})$ & -105.6 & 2.9 & 0.43 & 0.08 & 0.35 \\
\hline Mz_VTS0_4b1 $(n=1)$ & Pyroclastic $(90 \mathrm{~cm})$ & -88.2 & - & 0.76 & 0.12 & 0.64 \\
\hline Mz_VTS0_4b3 $(n=2)$ & Pyroclastic $(90 \mathrm{~cm})$ & -98.4 & 4.7 & 0.51 & 0.05 & 0.46 \\
\hline Mz_VTS0_5a2 $(n=2)$ & Pyroclastic $(105 \mathrm{~cm})$ & -97.7 & 3.8 & 0.56 & 0.07 & 0.49 \\
\hline Mz_VTS0_5a3 $(n=2)$ & Pyroclastic $(105 \mathrm{~cm})$ & -96.8 & 0.3 & 0.49 & 0.07 & 0.42 \\
\hline Mz_VTS0_5b3 $(n=2)$ & Pyroclastic $(120 \mathrm{~cm})$ & -91.1 & 4.6 & 0.87 & 0.18 & 0.70 \\
\hline Mz_VTS0_5b5 $(n=2)$ & Pyroclastic $(120 \mathrm{~cm})$ & -89.7 & 2.3 & 0.78 & 0.14 & 0.65 \\
\hline Mz_VTS0_6a1 $(n=2)$ & Pyroclastic $(135 \mathrm{~cm})$ & -101.3 & 1.2 & 0.39 & 0.02 & 0.37 \\
\hline Mz_VTS0_6a2 $(n=2)$ & Pyroclastic $(135 \mathrm{~cm})$ & -109.8 & 1.1 & 0.29 & 0.02 & 0.27 \\
\hline Mz_VTS0_6b1 $(n=2)$ & Pyroclastic $(150 \mathrm{~cm})$ & -101.4 & 0.4 & 0.44 & 0.06 & 0.38 \\
\hline Mz_VTS0_6b3 $(n=2)$ & Pyroclastic $(150 \mathrm{~cm})$ & -99.5 & 0.7 & 0.49 & 0.07 & 0.42 \\
\hline Mz_VTS0_6b4 $(n=2)$ & Pyroclastic $(150 \mathrm{~cm})$ & -106.4 & 0.1 & 0.38 & 0.02 & 0.36 \\
\hline Mz_VTS0_7A1 $(n=2)$ & Pyroclastic $(165 \mathrm{~cm})$ & -90.7 & 0.4 & 0.77 & 0.12 & 0.64 \\
\hline Mz_VTS0_7A2 $(n=2)$ & Pyroclastic $(165 \mathrm{~cm})$ & -104.8 & 2.8 & 0.30 & 0.02 & 0.28 \\
\hline Mz_VTS0_7b2 $(n=1) \dagger$ & Pyroclastic $(180 \mathrm{~cm})$ & -99.1 & - & 0.56 & n.d. & n.d. \\
\hline Mz_VTS0_7b5 $(n=2) \dagger$ & Pyroclastic $(180 \mathrm{~cm})$ & -100 & 1.5 & 0.48 & n.d. & n.d. \\
\hline Mz_VTS0_8a1 $(n=2)$ & Pyroclastic $(195 \mathrm{~cm})$ & -99.2 & 3.5 & 0.46 & 0.05 & 0.41 \\
\hline $\mathrm{Mz}_{-}$VTS0_8a2 $(n=1)$ & Pyroclastic $(195 \mathrm{~cm})$ & -108 & - & 0.36 & 0.04 & 0.32 \\
\hline Mz_VTS0_8a5 $(n=2)$ & Pyroclastic $(210 \mathrm{~cm})$ & -100 & 0.1 & 0.56 & 0.06 & 0.5 \\
\hline Mz_VTS0_10b2 $(n=1)$ & Pyroclastic $(225 \mathrm{~cm})$ & -97.2 & - & 0.66 & n.d. & n.d. \\
\hline Mz_VTS0_15a1 $(n=2)$ & Pyroclastic $(245 \mathrm{~cm})$ & -102.8 & 0.1 & 0.50 & n.d. & n.d. \\
\hline GM94-10 $(n=1)^{*}$ & Lava & -152.2 & - & 0.14 & n.d. & n.d. \\
\hline GM94-11 $(n=1)^{*}$ & Lava & -146.5 & - & 0.13 & n.d. & n.d. \\
\hline GM95-02 $(n=1)^{*}$ & Lava & -120 & - & 0.13 & n.d. & n.d. \\
\hline GM95-06 $(n=1)^{*}$ & Lava & -117.1 & - & 0.14 & n.d. & n.d. \\
\hline GM95-07 $(n=1)^{*}$ & Lava & -126.3 & - & 0.10 & n.d. & n.d. \\
\hline GM95-11 $(n=1)^{*}$ & Lava & -142.9 & - & 0.12 & n.d. & n.d. \\
\hline GM95-15 $(n=1)^{*}$ & Lava & -138.1 & - & 0.11 & n.d. & n.d. \\
\hline GM97-01 $(n=1)^{*}$ & Lava & -139.1 & - & 0.06 & n.d. & n.d. \\
\hline GM97-02 $(n=1)^{*}$ & Lava & -139.4 & - & 0.07 & n.d. & n.d. \\
\hline GM97-03A $(n=1)^{*}$ & Lava & -131.9 & - & 0.10 & n.d. & n.d. \\
\hline GM97-03B $(n=1)^{*}$ & Lava & -143.5 & - & 0.10 & n.d. & n.d. \\
\hline
\end{tabular}

${ }^{*}$ Measurements from DeGroat-Nelson et al. [2001].

${ }^{\dagger} \mathrm{H}_{2} \mathrm{O}$ contents from TCEA. 
ber. The adjusted precision is estimated to be 3-6 \%o for these samples.

Analytical problems were encountered when measuring the driest obsidian samples, i.e the effusive obsidians, by TCEA. The reason for this was that given the low total $\mathrm{H}_{2} \mathrm{O}$ (and hydrogen concentrations), significant material ( $>10 \mathrm{mg}$ ) had to be loaded into the furnace, which resulted in clogging and failure of the TCEA reaction chamber furnace. Consequently, the data on BGM obsidian lava were anomalous and unusable. We therefore supplemented our pyroclastic obsidian data set with published hydrogen isotopic data of DeGroat-Nelson et al. [2001], who made their measurements via step-heating and whole rock fusion methods on BGM effusive obsidians located near the outcrops sampled in this study.

Even though it has been reported that the TCEA-MS procedure returns an $\mathrm{H}_{2} \mathrm{O}$ content for the bulk sample with an accuracy of \pm 0.01 wt. $\%$ [Bindeman et al. 2012], no inter-laboratory standards for $\mathrm{H}_{2} \mathrm{O}$ quantification via TCEA exist; furthermore, a thorough $\mathrm{H}_{2} \mathrm{O}$ measurement error analysis on the instrument at the University of Frankfurt has not been made. Consequently, we sought an independent assessment of bulk $\mathrm{H}_{2} \mathrm{O}$ content and hydrous speciation through the FTIR method [e.g. Castro et al. 2012]. The bulk $\mathrm{H}_{2} \mathrm{O}$, along with the $\mathrm{H}_{2} \mathrm{O}$ and $\mathrm{OH}$-group species in splits of TCEAMS measured obsidian glasses were quantified using a Thermo-Nicolet FTIR Bench with attached Continuum microscope at the Johannes Gutenberg University in Mainz, Germany. Doubly polished pyroclastic obsidians, sectioned from pyroclast interiors so as to avoid surface alteration, and ranging in thickness $(\sim 160-$ $500 \mu \mathrm{m})$ were analyzed on spots $(\sim 50 \mu \mathrm{m})$ in transmission mode at a spectral resolution of $4 \mathrm{~cm}^{-1}$, using 256 scans and sample-free-path background spectra collected every 30 minutes. Sample thicknesses were determined to an accuracy of $\pm 5 \mu \mathrm{m}$ with a Mitutoyo digital micrometer. A $\mathrm{KBr}$ beamsplitter, and liquid $\mathrm{N}_{2}$-cooled MCT detector were configured on the FTIR system to yield maximum signal strengths over a broad bandwidth $\left(\sim 6000 \mathrm{~cm}^{-1}\right.$ to $<1000 \mathrm{~cm}^{-1}$ spectral range). The relatively thick samples were required because of the need to resolve the hydrous species peaks at $4500 \mathrm{~cm}^{-1}$ and $5200 \mathrm{~cm}^{-1}$, which correspond to $\mathrm{OH}$ and $\mathrm{H}_{2} \mathrm{O}$ molecular groups, respectively. In addition, some samples with rather low bulk $\mathrm{H}_{2} \mathrm{O}$ contents $(<0.1$ wt.\%) exhibited good quantifiable mid-IR absorbance peaks at $3550 \mathrm{~cm}^{-1}$. We used a linear baseline to measure the different peaks' heights, and, these absorbance values were then input into Beer's Law. As Beer's law also requires a glass density and extinction coefficient values, we calculated glass densities using the approach of Lange and Carmichael [1990] and used extinction coefficients for rhyolite glass from Ihinger et al. [1994]. Finally, we estimated detection limits of $\sim 0.005$ wt. $\% \mathrm{H}_{2} \mathrm{O}$ based on the analysis of multiple spots yielding the $3550 \mathrm{~cm}^{-1}$ peak and observing its topological change as we collected unknown spectra at various scan rates.

\subsection{Modeling volcanic degassing trends}

The analytical measurements yield $\mathrm{H}_{2} \mathrm{O}$ bulk concentration (wt.\%) and corresponding $\delta \mathrm{D}$ (in \%o) values of pyroclastic obsidians (Table 1). We plotted these two parameters against one another to investigate "degassing trends", particularly by fitting them with various idealized degassing models, including: closedsystem, open-system, and batched degassing [e.g. Newman et al. 1988; Taylor 1991; Rust et al. 2004]. As single-stage model fits were not sufficient to match the data, we additionally investigated "two-staged" paths, specifically, closed-to-open and closed-to-batched, both of which simulate the magma becoming progressively more open as degassing proceeds [e.g. Eichelberger et al. 1986].

All model simulations were performed with the Matlab program VolcDeGas [Walter 2017; Walter and Castro 2020, Supplementary Material], which allows users to input various magmatic conditions to investigate different degassing mechanisms in hydrous rhyolite melts. VolcDeGas outputs comprise plots of $\delta \mathrm{D}$ vs. $\mathrm{H}_{2} \mathrm{O}$ superimposed on, and statistically fit to, the original analytical data. The program's input parameters include: 1) the initial and final $\mathrm{H}_{2} \mathrm{O}$ content, 2) the initial $\delta \mathrm{D}$ of the melt, 3) the hydrous speciation (determined by FTIR and confirmed and extrapolated to other higher-thanobserved $\mathrm{H}_{2} \mathrm{O}$ contents by the program), 4) the temperature (when hydrous speciation data are unavailable), and 5) the speciation-dependent fractionation factors (also computed by VolcDeGas based on measured $\mathrm{H}_{2} \mathrm{O}$ speciation). VolcDeGas calculates solutions to simple closed-system (mass conservative), open- (Rayleigh distillation), and batched-system equations by mass balance for each degassing step [e.g. Taylor 1991; Castro et al. 2014].

Batched systems were modeled by using sequential closed-system steps, similar to the approaches of Taylor [1991] and Castro et al. [2014]. Each step is treated as a "vapour reservoir" filling event, whereby the reservoir is imaginary but could represent cracks or bubbles. During the initial filling calculation, VolcDeGas iteratively determines the equilibrium composition of $\delta \mathrm{D}$ in both the vapour and melt for a given amount of $\mathrm{H}_{2} \mathrm{O}$ loss into the reservoir. When the filling reaches the step-size determined value of $\mathrm{H}_{2} \mathrm{O}$ decrease, the vapour is then instantaneously removed from the system. The result of this calculation procedure is a slightly curved line corresponding to a single closed system step [e.g. Dobson et al. 1989; Walter and Castro 2020].

In all degassing systems, the step size must be specified, which is the fractional amount of $\mathrm{H}_{2} \mathrm{O}$ exsolved and lost from the initial magmatic $\mathrm{H}_{2} \mathrm{O}$ budget during each step. In a simple closed system, this amount of $\mathrm{H}_{2} \mathrm{O}$ loss is fixed because the vapour is forced to stay 
in isotopic equilibrium with the initial $\mathrm{H}_{2} \mathrm{O}$ budget. However, in batched- and open-system cases, because the amount of "residual" $\mathrm{H}_{2} \mathrm{O}$ is continually updated with each step, and decreases, a fractional amount of this residual $\mathrm{H}_{2} \mathrm{O}$ produces variable step sizes that will get incrementally smaller as the bulk $\mathrm{H}_{2} \mathrm{O}$ budget diminishes with each degassing step [Walter and Castro 2020].

We assessed the most permissible degassing scenario for the BGM eruption based on VolcDeGas' internal goodness-of-fit to data assessment routine [Walter and Castro 2020]. More specifically, the best-fit trend for each degassing system is the result of hundreds of separate computed degassing trends, each taking into account the user input data and degassing intervals (e.g. step size). The best-fit is then selected by VolcDeGas on the basis of its own determination of the minimum Root Mean Square Error (RMSE), which indicates the standard deviation between predicted $\delta \mathrm{D}-\mathrm{H}_{2} \mathrm{O}$ values and the observed natural data [Walter and Castro 2020]. Two-stage degassing models, furthermore, have a transition point corresponding to the changeover from closed-system process and the onset of a new mechanism, be it batched or open-system degassing. These transition points were objectively chosen by VolcDeGas, which finds the best-fit transition with an iterative approach in which it firstly calculates the initial bestfit closed-system degassing segment via the aforementioned calculation-intensive procedure. Next, the program tests different transition point positions along the previously calculated closed-system segment by adjusting both the input parameters and the resultant second stage degassing trend. VolcDeGas automatically adjusts the transition point to achieve the maximum coefficient of determination $\left(\mathrm{R}^{2}\right)$ and minimum RMSE values. Additional information on how VolcDeGas operates including its validation with case study data can be found in Walter and Castro [2020].

\section{Results}

4.1 Field evidence for hybrid volcanism at BGM: key insights from recently active rhyolite volcanoes

Recent eruptions at Chaitén and Cordón Caulle provided evidence of how rhyolite events can progress, showing in a clear and unprecedented manner that transitions from explosive to effusive activity may be exceptionally drawn-out (months-long), rather than sharp [e.g. Eichelberger 1975; Giachetti et al. 2020]. At both volcanoes, hybrid effusive-pyroclastic venting lasted until the lavas were nearly completely emplaced, meaning that the initial purely explosive and final effusive phases were short (weeks-long), effectively "bookending" activity dominated by this hybrid style. Both Chaitén and Cordón Caulle exhibited hybrid venting for months to upwards of a year [Castro et al. 2013; Pal- lister et al. 2013, Supplementary Material]. We contend that field evidence for simultaneous venting of pyroclasts and lavas should be present in older systems that erupted this way, yet were not observed. We therefore firstly describe the depositional record at Chaitén and Cordón Caulle to establish a framework to interpret features indicative of hybrid activity in and on BGM's lava flow. These features, for all intents and purposes, argue for a drawn-out transition from initial explosive to effusive of activity during the eruption of BGM. As we have no firm constraints on temporal scale for activity at BGM, we can only speculate that if eruption rates at BGM resembled those of the Chilean events ( tens of $\mathrm{m}^{3} \mathrm{~s}^{-1}$ Pallister et al. [2013]), the similarity in effusive eruption deposit volumes $\left(\sim 1 \mathrm{~km}^{3}\right)$ may imply similar months-long hybrid activity at BGM.

The salient depositional features formed during Chaitén and Cordón Caulle's hybrid eruptions comprise mixtures of pyroclastic and effusive materials, ranging from very large-scale depositional structures to microscopic textures. The key deposits include: 1) glassy to pumiceous ballistic bombs consisting of various textural components [e.g. breccia: Schipper et al. 2021] and deposited in vent-proximal locations [e.g. Castro et al. 2014]; 2) expansive (100s m long) pyroclastic ridges positioned in middle of the lava field [e.g. Tuffen et al. 2013; Castro et al. 2014]; 3) unconsolidated to well welded pyroclastic fall deposits mantling the tops of lava; 4) interspersed mixtures of pyroclasts and coherent obsidian lava that occur in joint-like channel structures-so-called tuffisite veins-that crosscut massive lava bodies [Tuffen et al. 2003; Wadsworth et al. 2018]. With the clear physical evidence for hybrid eruption at Chaitén and Cordón Caulle in hand, in the following passages, we describe evidence for three of the four features that indicate significant hybrid activity at BGM.

\subsubsection{Ballistic bomb fields}

Ballistic bomb activity characterized the early transition from purely explosive activity to hybrid venting at both Chaitén and Cordón Caulle volcanoes [Schipper et al. 2013; Castro et al. 2014]. The bomb fields at both Chaitén and Cordón Caulle are well preserved due to the topography and emplacement patterns of the lavas, which precluded burial of the bombs by advancing lava. In both locations, ballistic bombs ranging from decimeters to a couple of meters in size litter the near-vent region, but can also be found cratering the landscape several $\mathrm{km}$ from the vent.

At BGM, the lava fields are so extensive that most vent regions are obscured by lava. Our field work, which focused on the south-central flow fields and tephra fall deposit (Figure 1), did not reveal the presence of a bomb field at BGM. However, because the BGM eruption occurred along a fissure, and the north end of this fissure was not overtopped by lava [Ander- 
son 1933; Donnelly-Nolan et al. 2016], abundant ballistic bombs can be found resting on tephra aprons and the many satellite domes at these locations [DonnellyNolan et al. 2016, personal communication]. We suggest that the lack of bombs at BGM in more central fissure locations may be due to the overrunning of the bomb field by the expansive BGM lava flows.

\subsubsection{Pyroclastic ridges}

Pyroclastic ridges at BGM are conspicuous accumulations of reddish brecciated material that have distinct surface texture (e.g. an abundance of fine ash and lapilli sized particles) and componentry that is atypical of rhyolite lava, which comprises coarse (decimeter to meter sized) blocky lava with varying vesicularity (Figure 1, Figure 2, Figure 3A, B). Anderson [1933] suggested that these ridges are evidence of how lavas at BGM effused and destroyed large pumice cones and that remnants of these accumulations-now present as pyroclastic ridges-are now exposed in the southern part of the flow (Figures 1 and 2). Eichelberger [1975] recognized these distinct breccia zones too, and noted that their arcuate shape and topographic relief conform to the inferred flow emplacement mechanism and sequence. However, based on a lack of pumice bombs, as is seen in the tephra cones to the north of BGM, Eichelberger [1975] argued that these ridges were not rafted pyroclastic cones but rather lava bodies that had brecciated in place and were subsequently hydrothermally altered to clay.

The breccia ridges are distributed at BGM in a radial pattern with respect to the central vent of the flow, which is the highest point from which they may have been sourced (Figure 1). Ridges comprise large (tens of $\mathrm{m}$ in width by several hundreds of $\mathrm{m}$ in length) curved zones that outcrop predominantly in the SW flow interior (Figures 1 and 2), however fragments of ridges are also present in the NE and SE flow sections (Figure 1). The ridges are distinctly pinkish-red and highly vegetated in contrast to the barren grey and black lava that surrounds them (Figure 3A, B).

Close-up examination of the components and textures of breccia zones (Figure 2) reveals that Eichelberger's [1975] hypothesis positing in situ autobrecciation of lava could not have been the case. Specifically, the breccia zones do in fact contain all of the components of tephra cones [Donnelly-Nolan et al. 2008], including pristine pumice bombs, highly vesicular pumices, dense obsidian, and polymictic breccia, comprising clasts ranging from ash to block-size $(\sim 1 \mathrm{~mm}$ to $1 \mathrm{~m}$; Figure 2$)$. The breccia zones, furthermore, have undergone varying degrees of welding, as evidenced by zones of vitrophyric textured lava, observable on both mesoscopic and microscopic scales (Figure 2E-G, Figure 4). Welding would not be expected if these zones formed solely by superficial brecciation of relatively cool and blocky surface crust (Fig- ure 3).

Breccia zones are rich in fine red ash, which forms a supporting matrix to larger clasts (Figure 2D; Figure 4). The clasts within the breccia range from dense glassy to vesicular grains with internal frothy zones mantled by outer glassy selvages (Figure $2 \mathrm{~F}$ ). Such textures are indicative of fragmentation of initially low vesicularity material followed by later frothing of $\mathrm{H}_{2} \mathrm{O}$-saturated melt. Similar textures and structures are abundant in bombs from Chaitén, whose origin was directly linked to hybrid activity from Chaitén's tephra cone [Castro et al. 2012].

The aforementioned field observations and textural and lithological features of BGM's breccia zones indicate that these features must be of pyroclastic origin. Unlike the typical flow-top lava, which lacks a matrix component, and comprises large (decimeter to meter scale) coherent, separable and movable blocks (Figure $3 \mathrm{~A}, \mathrm{~B})$, the breccia is much more cohesive at the outcrop scale and lacks evidence of hydrothermal alteration (e.g. clay mineralization, perlite, etched glass [Eichelberger 1975]). The welded areas within breccia zones, furthermore, have ignimbrite-like foliated textures (Figure $2 \mathrm{E}-\mathrm{G}$ ), suggesting that these pyroclastic materials were hot when they were incorporated into the lava. Thin sections of welded breccia reveal partially to completely sintered pyroclasts, some of which retain their original outlines and are moderately to severely stretched into a eutaxitic foliation (Figure 4). Some larger clasts $(\sim 5 \mathrm{~cm})$ appear to have re-expanded after some time in the flow, in turn resulting in distortion of the foliation. Foliated and revesiculated structures are absent in the "normal" lava flow flow top breccias.

The textures of the breccia zones are consistent with the production of their inherent pyroclasts from a venting cone, wherein the thermal energy and $\mathrm{H}_{2} \mathrm{O}$ remaining in freshly erupted fragments would foster deformation, welding, bubble nucleation and growth [Castro et al. 2005b]. These characteristics, along with the macroscopic form and structure of the ridges, in turn require that the pyroclastic materials now making up the breccia ridges were swept away by a moving mass of lava shortly after they were freshly lain down. Breccia ridges found embedded within the vast Cordón Caulle lava flow formed exactly in this manner [Tuffen et al. 2013; Castro et al. 2014, Supplementary Material], and thus, provide a model of how this could have transpired at BGM.

\subsubsection{Pyroclastic air-fall lava mantles}

Evidence for pyroclastic fallout during lava emplacement is difficult to find on obsidian flows. This is due in part to the pervasive fracturing that the lava surface undergoes as it deforms and cools. Unconsolidated pyroclastic material deposited on that dynamically deforming and brecciated surface may be ingested 

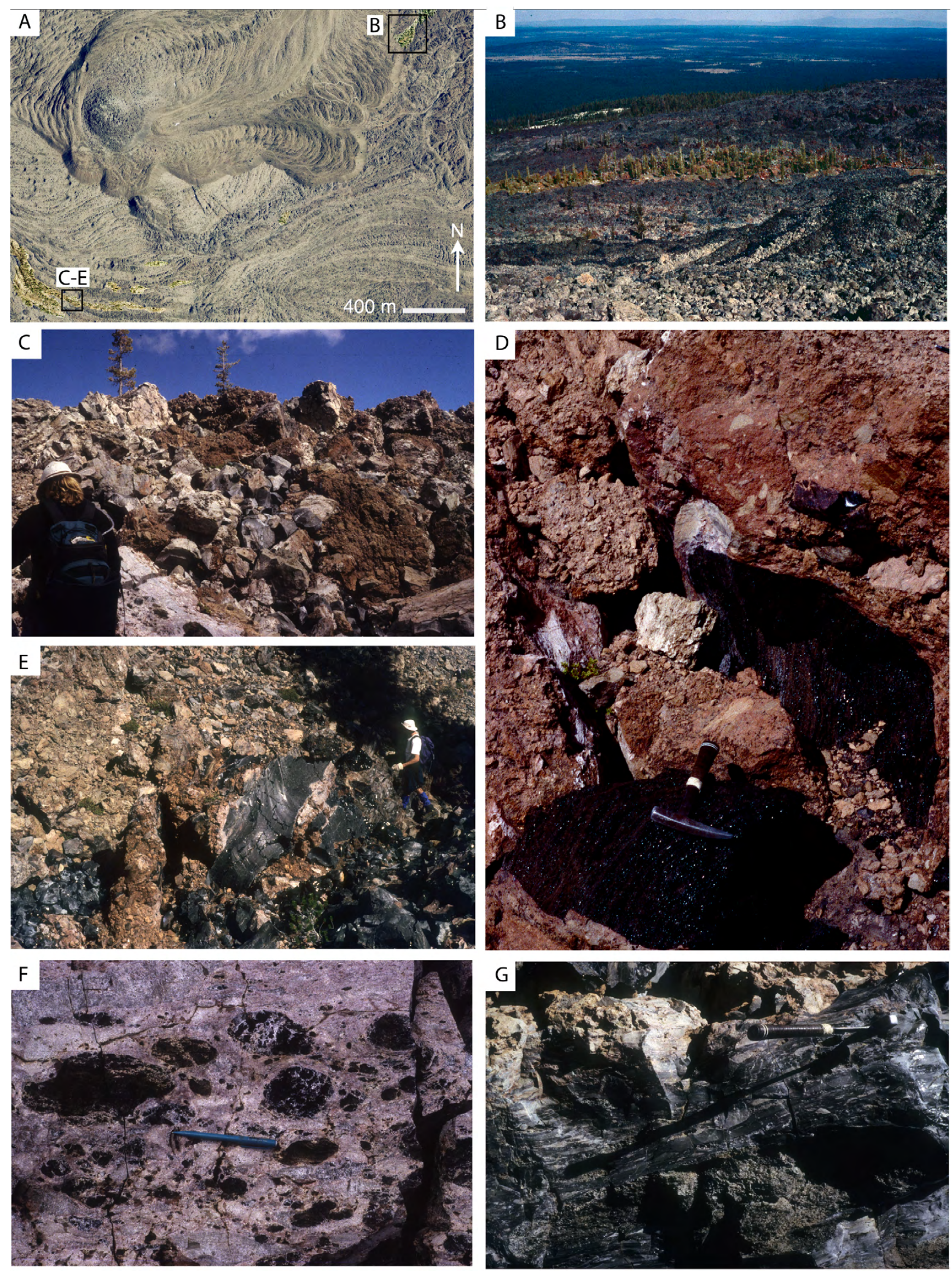

Figure 2: [Caption on next page] 
Figure 2: [Previous page] [A] NAIP (National Agriculture Imagery Program) satellite image of Big Glass Mountain. Breccia zones are highlighted by color enhancement in the lower left and upper right to distinguish them from "normal" flow top lava textures. Frames [B] and [C-E], correspond to field photographs of the boxed in areas in frame [A]. These views show breccia zones [C] comprising meter-scale massive red breccia, pumice and obsidian bombs [D], and ash-rich polymictic breccia fragments [D]. Some breccia zones contain massive obsidian blocks interwoven with channels containing unconsolidated pyroclasts [E]. Such features may represent megatuffisites that were actively venting as lava effused from the vent [e.g. Castro et al. 2014]. Frames [F] and [G] show representative welding textures in breccia blocks that most likely underwent intense shear deformation during emplacement of the lava flow. That fragments as small as a centimeter are re-expanded through vesiculation (see rounded clasts in frame [F]) and also densely welded [G] indicates that pyroclasts retained significant heat and $\mathrm{H}_{2} \mathrm{O}$ during the process of post-fragmentation welding. In the most densely welded case, breccia has a eutaxitic foliation like that found in welded tuffs. Such textures-not found in "normal" flow top breccia-indicate that little if any time elapsed between the explosive activity that made the breccias and lava emplacement that swept them away.
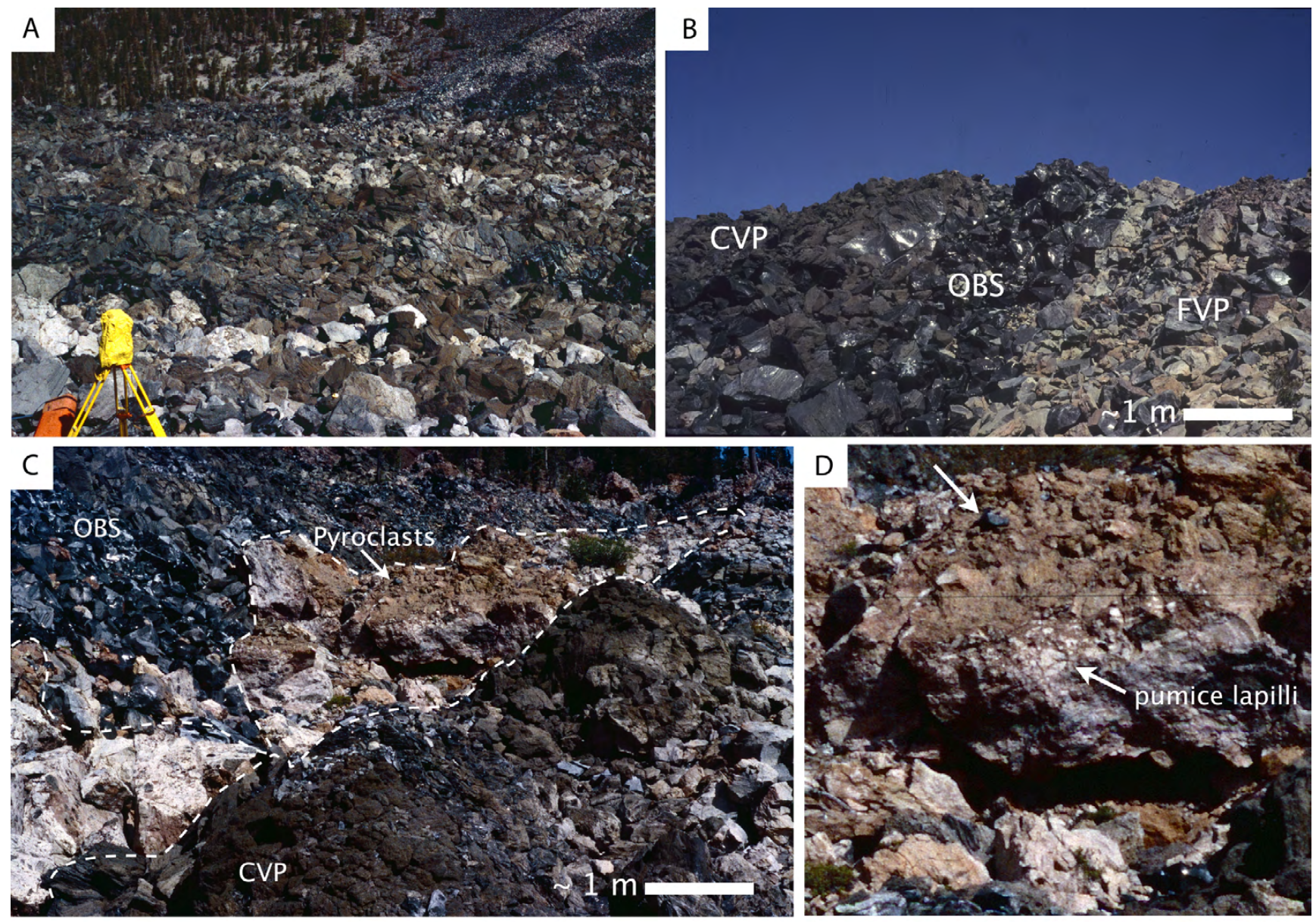

Figure 3: $[A]-[B]$ Field photographs showing typical lava flow top morphology and texture on Big Glass Mountain. Lava comprises meter-sized angular blocks of finely and coarsely vesicular pumice (FVP and CVP) and dense black obsidian (OBS). Frames [C] and [D]) show rare exposures of pyroclastic mantle deposits on normal obsidian lava flow top. In frame [C], pyroclastic deposits are confined to a small swale (enclosed in white dashed lines) in the flow, which corresponds to a valley formed during folding of the flow top. These pyroclasts are shown in magnified view in frame [D]. Like pyroclastic material in the breccia zones, these deposits have a reddish hue that contrasts sharply from the surrounding lava. The overall grain size is highly variable, ranging from lapilli to bomb size fragments, and grading from blocky pyroclastic material on top to progressively denser partially welded pyroclasts in contact with the lava at its base. The presence of pumice lapilli and unconsolidated obsidian blocks suggest these materials were deposited from the air on an actively effusing lava (see also equivalent features at Cordón Caulle in the Supplementary Material). 

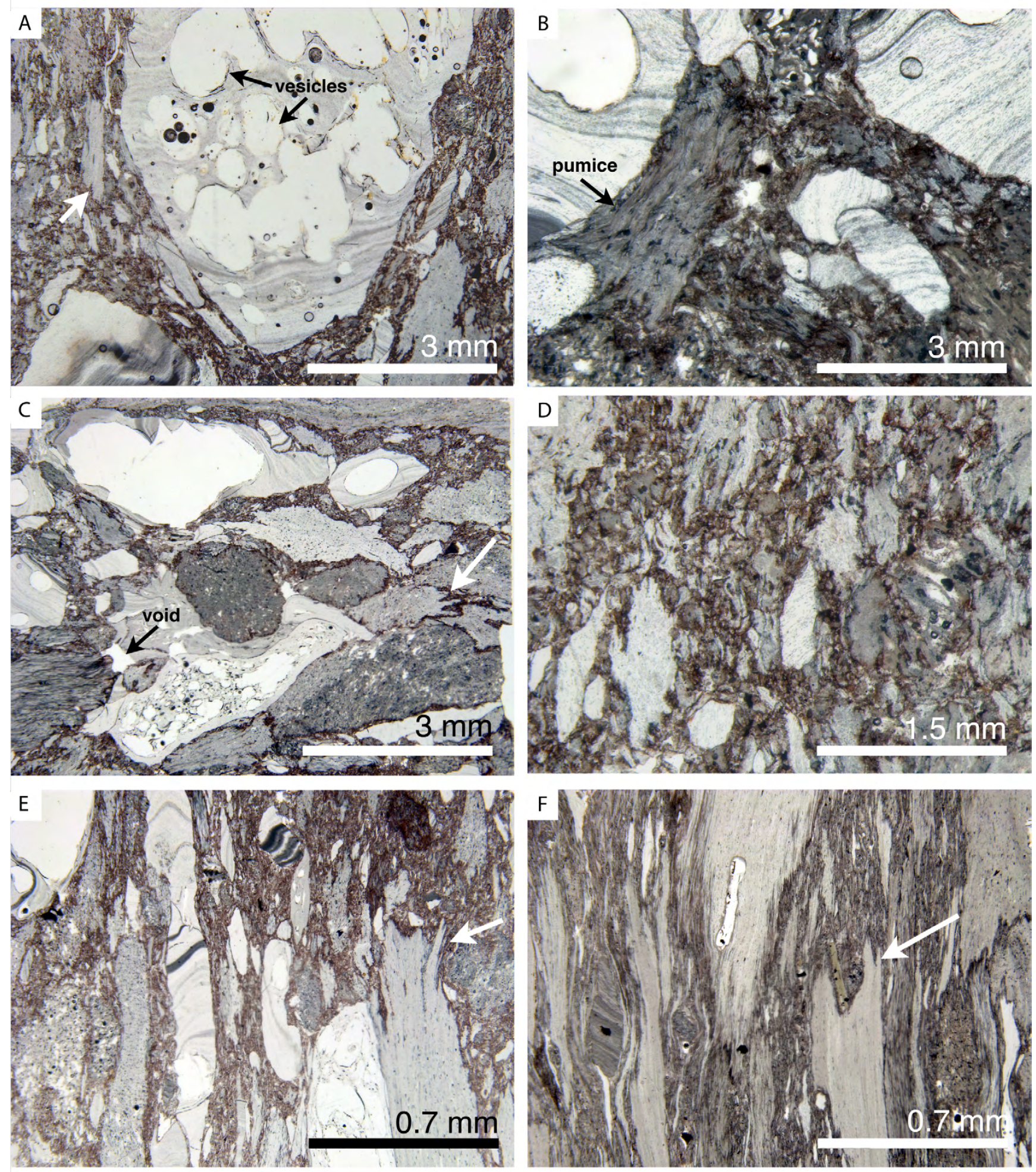

Figure 4: Optical light photomicrographs of breccia material sampled from the BGM lava flow. In thin section, the breccia comprises variable amounts of fine ash matrix and lapilli-sized clasts. The fragments themselves consist of dense, often flow banded glass, to moderately vesicular pumice $[A],[B]$. Frames $[A]$ and $[B]$ show relatively outsized flow banded obsidian clasts that underwent secondary vesiculation that disrupts flow banding. Such evidence, along with prevalent fiamme structures (white arrows in frames [A], [C], [E], and [F]) indicates that postfragmentation welding and expansion occurred while material was pyroclasts were still hot, relatively hydrous, and above the glass transition point [ $740^{\circ} \mathrm{C}$ : Castro et al. 2005a]. Frame [C] shows the abundance of diverse clasts with sutured grain boundaries and some remnant pore space (void). Frames [D] through [F] indicate the progression of increasing welding intensity in dense sintered ash, from moderate [D] to extreme [F]. 
by the flow itself as cracks provide space for clasts to fall into. This behavior was observed at both Cordón Caulle and Chaitén, where newly effused near-vent lava was initially covered with falling pyroclastic debris, but then quickly incorporated that thin mantle as the flow moved from the vent (Supplementary Material; see also Figure 1 in Castro et al. [2014]).

At BGM, however, some sections of lava remain draped with thin pyroclastic units (Figure 3C, D). These rare, meter-thick exposures consist of poorly sorted, unconsolidated pumice and obsidian blocks that grade downward into poorly welded pumice and ash deposits. The pumice lapilli then grade into moderately well welded breccia whose foliation is parallel to the flow surface. In a similar context to the breccia ridges, we interpret these deposits as products of hot pyroclastic deposition-likely by proximal air fall-and incipient welding of the pyroclasts as they accumulated on a hot flow surface.

Nearly identical pyroclastic veneers are found on the distal parts of the Cordón Caulle lava, corresponding to products that were effused early in the eruption when simultaneous pyroclastic venting was elevated in energy (Supplementary Material; Figure S1). Like those at BGM, these deposits are thin $(\sim 1 \mathrm{~m})$, spatially constrained $\left(2-5 \mathrm{~m}^{2}\right)$, and exhibit the same sequence of coarse to fine pyroclasts overlying incipiently welded tuffs on the flow surface (Supplementary Material; Figure S1). The striking similarity between field relations of these airfall deposits, along with the observed mode of formation at Cordón Caulle, strongly supports the field evidence for simultaneous effusive-explosive activity at BGM.

\subsection{Hydrous geochemical signature of degassing:} $\mathrm{H}_{2} \mathrm{O}-\delta \mathrm{D}$ measurements

Figure 5 shows the results of $\mathrm{H}_{2} \mathrm{O}$ (via FTIR) and hydrogen isotopic measurements (TCEA) on BGM pyroclastic obsidians. Also shown for reference are $\mathrm{H}_{2} \mathrm{O}-\delta \mathrm{D}$ data from BGM lavas analyzed by DeGroat-Nelson et al. [2001]; these are included because they extend the range in data to lower $\mathrm{H}_{2} \mathrm{O}$ contents, thereby providing a more complete picture of degassing history (e.g. see also Giachetti et al. [2020], who use data from DeGroatNelson et al. [2001]). The collective trend in $\delta \mathrm{D}$ is at first subtle (Figure 5) followed by a very pronounced drop in $\delta \mathrm{D}$ quite similar to those of other rhyolite systems (e.g. Inyo Domes [Taylor 1991]; Chaitén [Castro et al. 2014]).

The distribution of $\mathrm{H}_{2} \mathrm{O}$ contents of pyroclastic and lava samples shows a range of $\mathrm{H}_{2} \mathrm{O}(\sim 1.1$ to $\sim 0.1 \mathrm{wt} . \%)$, which are similar to, and within the range of values observed at other rhyolite systems, including Chaitén [e.g. Castro and Mercer 2004; Castro et al. 2012; Forte and Castro 2019, Figure 5]. We interpret these hydrous data to represent the true "magmatic $\mathrm{H}_{2} \mathrm{O}$ " component and contend that BGM pyroclasts have not suffered any post-depositional $\mathrm{H}_{2} \mathrm{O}$ loss due to, for example, hot deposition and slow cooling of clasts within the pyroclastic pile. Drawing on the work of Castro et al. [2012], who performed diffusive $\mathrm{H}_{2} \mathrm{O}$ outgassing calculations of 1 -cm-sized spherical obsidian fragments at $625^{\circ} \mathrm{C}$, we note that particles of this size require exceedingly long timescales $(\sim 340$ days) to diffusively release just a minor amount of $\mathrm{H}_{2} \mathrm{O}(\sim 0.2$ wt.\% in the interval $0.8-$ 0.6 wt. $\% \mathrm{H}_{2} \mathrm{O}$ [Castro et al. 2012]). As it seems untenable that a pyroclast could stay hot for upwards of a year within a deposit, notwithstanding the potential for significant cooling during that pyroclast's flight, we believe that the $\mathrm{H}_{2} \mathrm{O}$ contents measured on pyroclastic (and effusive) obsidians are robust records of hydrous geochemical processes during eruption.

As shown in Figure 5, the $\delta \mathrm{D}$ of obsidians measured in this study (Table 1 ) range from $-88.1 \%$ at high$\mathrm{H}_{2} \mathrm{O}$ to $-116.6 \%$ at the low $-\mathrm{H}_{2} \mathrm{O}$ limit. However, effusive obsidian data of DeGroat-Nelson et al. [2001] extend the range of BGM values to extremely deuteriumdepleted values $(\sim-152 \%$ o $)$ at low bulk- $\mathrm{H}_{2} \mathrm{O}$ contents. Finally, we found no systematic variation in either $\mathrm{H}_{2} \mathrm{O}$ or $\delta \mathrm{D}$ with stratigraphic position in the pyroclastic deposit (Table 1). This corroborates the results of Giachetti et al. [2020], whose own $\mathrm{H}_{2} \mathrm{O}-\delta \mathrm{D}$ data also lack a vertical trend in these variables. The lack of pattern may stem from the eruption of BGM along a fissure, and the possibility that pyroclastic lobes sourced from different vents might overlap with one another [C. Dan Miller, 2007, personal communication], thereby colluding potential systematic variation in hydrous component values.

\subsection{Modeling BGM degassing with VolcDeGas}

In order to investigate potential degassing mechanisms that could have given rise to this geochemical trend, we used VolcDeGas, a Matlab-based utility for modeling degassing trajectories [Walter and Castro 2020]. VolcDeGas allows the user to determine the statistically best-fit degassing paths to natural $\delta \mathrm{D}-\mathrm{H}_{2} \mathrm{O}$ data by simulating single and multi-staged degassing paths (e.g. closed-to-open system). The accuracy of these model paths is objectively determined by the program through an iterative data-fitting algorithm [further details in Walter and Castro 2020].

Modeling potential BGM degassing paths required that initial pre-eruptive conditions (e.g. $\mathrm{H}_{2} \mathrm{O}$ content and $\delta \mathrm{D}$ ) of the magma be established as starting points for VolcDeGas simulations. Waters et al. [2015] and Waters and Lange [2016] determined the storage conditions of BGM rhyolite based on phase petrology experiments and plagioclase hygrometry. Their results suggest a range of possible pre-eruptive $P-T$ conditions $\left(T=\sim 850-930^{\circ} \mathrm{C} ; P=\sim 25-80 \mathrm{MPa}\right)$, that collectively imply an initial volatile budget of $\sim 2-4$ wt. $\% \mathrm{H}_{2} \mathrm{O}$. We have chosen to run models based on the average of these estimates, i.e. a pre-eruptive water content on the order 


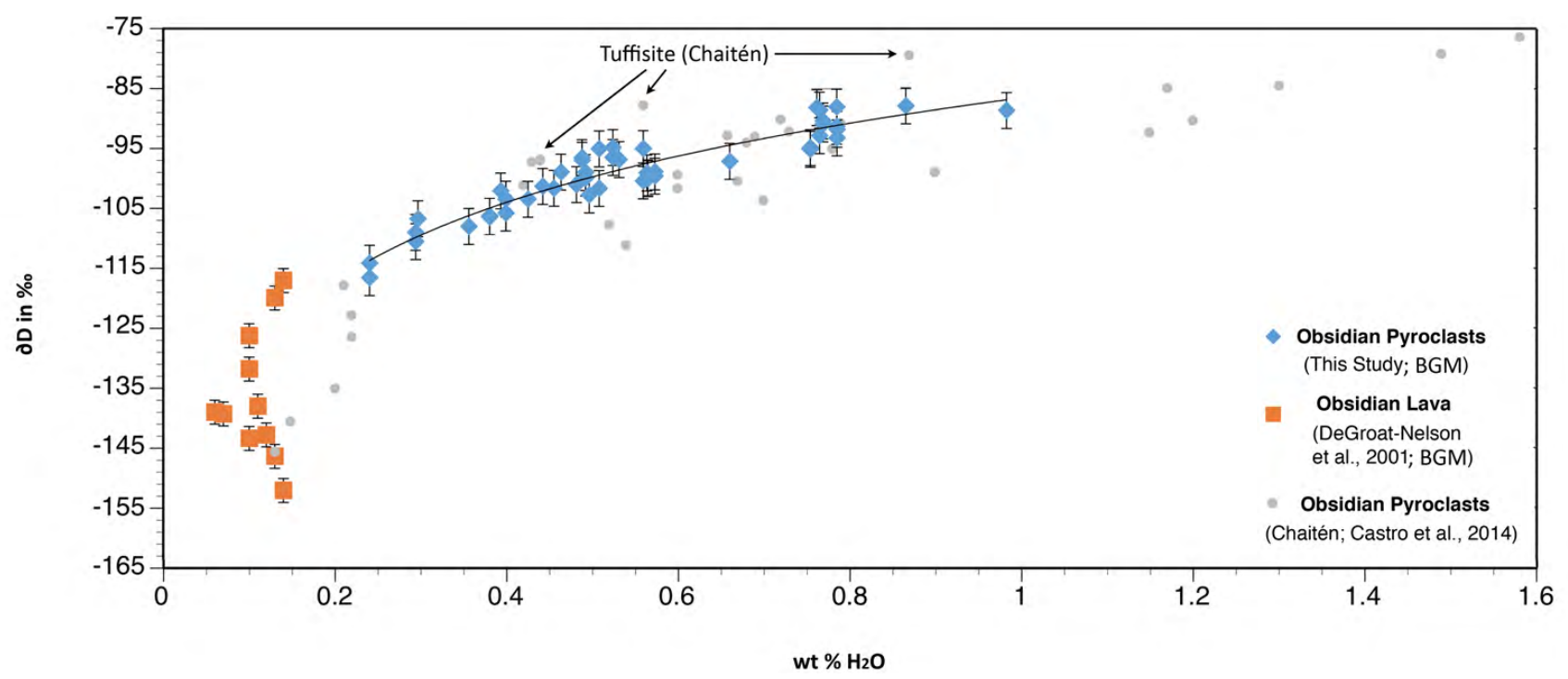

Figure 5: $\delta \mathrm{D}-\mathrm{H}_{2} \mathrm{O}$ (bulk) compositions of Big Glass Mountain rhyolite. Blue diamonds are obsidian pyroclasts analyzed in this study whereas orange squares are data collected by DeGroat-Nelson et al. [2001] on flow margin obsidian lavas. Grey circles are data derived from pyroclasts sampled from Chaitén volcano by Castro et al. [2014]. Error bars demarcate the measurement uncertainty for the TCEA-method applied in this study (isotopic error is $\pm 3 \%$ ), whereas the DeGroat-Nelson et al. [2001] data carry a $\pm 2 \%$ error. Measurement uncertainty in $\mathrm{H}_{2} \mathrm{O}$ contents (determined by FTIR; 0.01 wt.\%) are well within the breadth of the symbols. The curve fit $\left(\mathrm{R}^{2}=0.88\right.$ ) to the pyroclastic obsidian data is a logarithmic expression of form: $y=17.6 \ln (x)-87.7$; meant for statistical representation of trend and not as a degassing model.

of 3 wt. $\% \mathrm{H}_{2} \mathrm{O}$, consistent with an intermediate pressure. As $\mathrm{CO}_{2}$ went undetected in all measured obsidians [e.g. see also Giachetti et al. 2020], we proceeded with modeling under pure $\mathrm{H}_{2} \mathrm{O}$-saturated conditions. The initial $\delta \mathrm{D}$ of the magma is not known a priori, however, for modeling degassing paths this parameter is varied iteratively over a set range of possible starting conditions by the program that lead to a best fit to data [e.g. Castro et al. 2014; Giachetti et al. 2020]. In particular, the best fit models described below (e.g. twostaged closed-to-open and batched) were achieved with initial $\delta \mathrm{D}$ of $-68 \%$, which corresponds well with values measured on similarly aged hydrous rhyolitic obsidians $\left(\sim 3.1 \mathrm{wt} . \% \mathrm{H}_{2} \mathrm{O}\right)$ from Little Glass Mountain [Taylor et al. 1983].

Figure 6A, B shows VolcDeGas model fits to natural data assuming a single-staged (either closed- or opensystem) degassing mechanism. In general and perhaps unsurprisingly, single-staged models do not fit the complete range of data. In particular, the closedsystem degassing path from an initial $\delta \mathrm{D}$ of $-70 \%$ o fits only the first segment of data ranging from approximately 1.0 to $0.5 \mathrm{wt} . \% \mathrm{H}_{2} \mathrm{O}$, resulting in poor RMSE and $R^{2}$ values ( $>14.7,0.8$, respectively). Open-system degassing starting at a $\delta \mathrm{D}$ of $-53 \%$ provides a better fit to the data than closed-system model (Figure 6B), however this model does not match the $\mathrm{H}_{2} \mathrm{O}$-rich samples at the start of the trend, which in part arises from the relatively high initial $\delta \mathrm{D}$ required to ensure that final degassing steps yield the very $\delta \mathrm{D}$-depleted values at low $-\mathrm{H}_{2} \mathrm{O}$ content (effusive obsidians). Overall, the open system (with a small degassing step $\sim 0.001$ wt. \%) yields moderately improved fit parameters (RMSE $=8.5, \mathrm{R}^{2}=0.89$ ) over the closed-system case, but still leaves much of the data not adequately fit.

The poor fits of single-stage models to the data (Figure $6 \mathrm{~A}, \mathrm{~B}$ ) imply that a two-staged, open-to-closed system model would globally fit the natural isotopic observations better [e.g. Taylor et al. 1983; Eichelberger et al. 1986; Newman et al. 1988; Giachetti et al. 2020]. Thus, in Figure $6 \mathrm{C}$ we show the results of a two-stage, closedto-open system path using an initial $\delta \mathrm{D}$ of $-68 \%$. The transition point $(0.4 \mathrm{wt} . \%)$ from closed- to open-system degassing was determined by VolcDeGas iterative fitting process [e.g. see Walter and Castro 2020], and signifies the best-fit change in degassing mechanism based on data. It is important to note that this transition point is purely empirical and does not implicate a sharp physical shift in eruptive activity in nature. As we can see in Figure 6C, the two-stage model conforms nicely to the data, yielding RMSE of $\sim 6.7$ and an $\mathrm{R}^{2}$ of 0.87 , a considerably better fit than the single-stage systems.

Another type of degassing mechanism is a batched system, whereby an initial closed-system step is followed by many smaller closed-system steps of everdecreasing size (batches). Taylor [1991] and Castro et al. [2014] both employed similar models to explain de- 

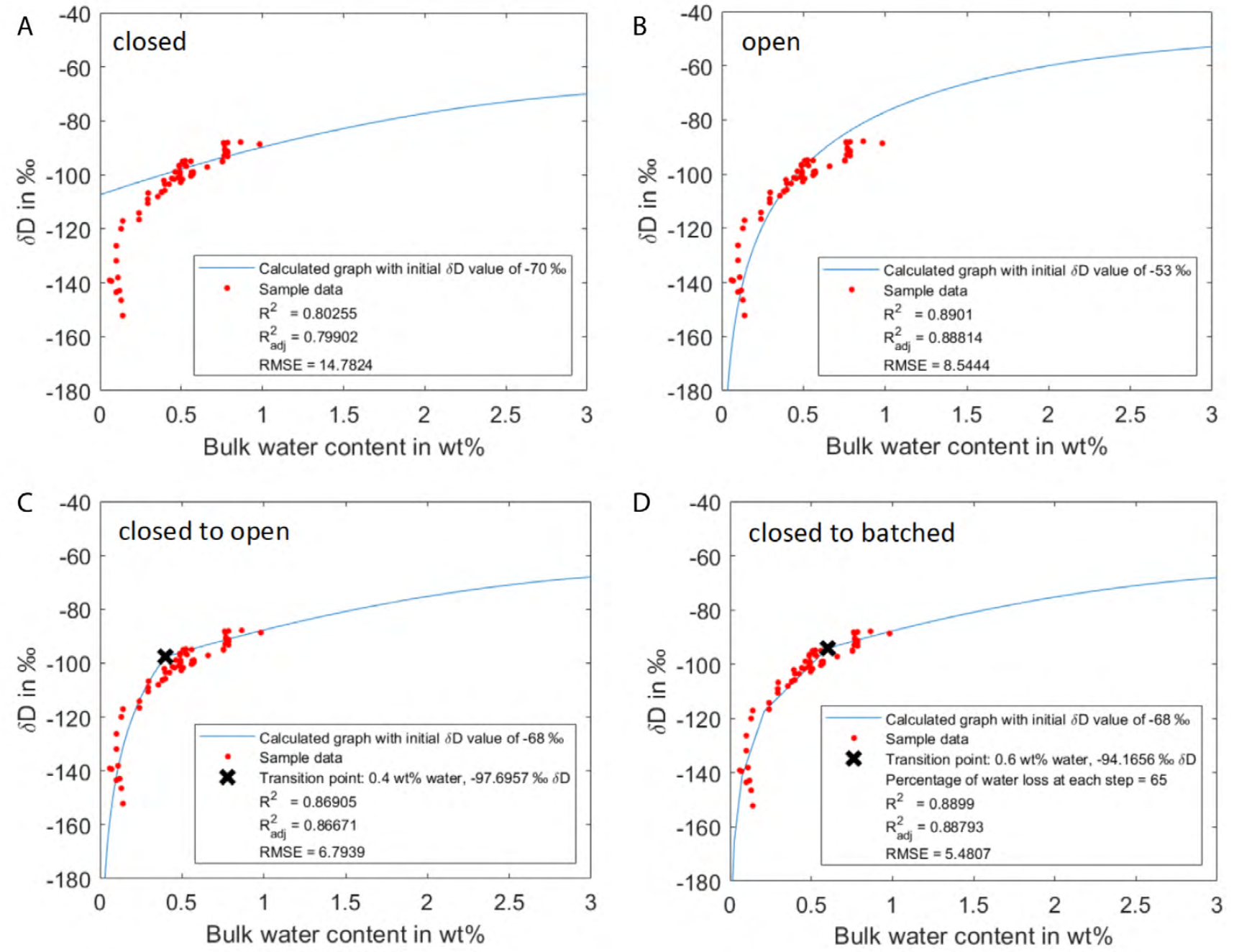

Figure 6: Best-fit VolcDeGas degassing simulations (blue curves) of measured $\delta \mathrm{D}-\mathrm{H}_{2} \mathrm{O}$ data (dots) from pyroclastic and effusive obsidians from Big Glass Mountain. VolcDeGas iteratively determines the best-fit path based on initial $\delta \mathrm{D}$ (in \%o) and $\mathrm{H}_{2} \mathrm{O}$ content, hydrous speciation calculations, variable degassing step size, and a degassing mode transition point (in the case of two-stage and batched degassing, frames [C] and [D], respectively). The best-fit parameters are shown in the figure insets along with statistical model errors. All simulations start at $3.0 \mathrm{wt} . \% \mathrm{H}_{2} \mathrm{O}$. Lava data points (at lowest $\mathrm{H}_{2} \mathrm{O},<0.2 \mathrm{wt}$.\%) are measurements made by DeGroat-Nelson et al. [2001]. Frames [A] and $[\mathrm{B}]$ show single-stage, end-member closed- and open-system degassing paths, which appear to only partially fit the high- and low- $\mathrm{H}_{2} \mathrm{O}$ content segments of data, whereas frames [C] and [D] indicate best fit models involving two-staged, closed-to-open system and batched-system degassing respectively [e.g. Taylor 1991].

gassing of the Inyo and Chaitén eruptions, respectively, and found good correspondence between models and data across all types of eruptive products. Accordingly, Figure 6D shows a batched degassing model applied to the BGM data, involving a large initial closedsystem step, followed by multiple repetitive batches of decreasing size ( $65 \% \mathrm{H}_{2} \mathrm{O}$ drop at each step).

As before, the degassing step size is determined by iterative best fitting in VolcDeGas. The variable, everdiminishing batched steps result in strong $\delta \mathrm{D}$ decrease at the end of degassing, and could mimic the tendency for and erupting magmatic system to "dry out" with time. Consequently, as the $\mathrm{H}_{2} \mathrm{O}$ budget decreases, there is less energy to supply plumes and explosive degassing [e.g. Schipper et al. 2013]. The result of this batched model (Figure 6D) shows a good statistical fit to the natural data. In comparison to the closed-to-open system (Figure 6C), the batched system yields a slightly better fit as determined by both $\mathrm{R}^{2}$ and RMSE values (Figure 6D).

In summary, the best fits to $\mathrm{BGM} \mathrm{H}_{2} \mathrm{O}-\delta \mathrm{D}$ data are those that involve either a two-stage degassing model, mimicking a progression from an early closed system to an open system, or a batched system with successively smaller batched-system steps that alleviate the volatile budget (Figure 6). 


\section{Discussion}

5.1 Physical evidence for simultaneous pyroclastic and effusive activity at Big Glass Mountain

Field relations, in addition to geochemical data, all suggest that hybrid explosive and effusive activity occurred at BGM. To our knowledge, only scant physical evidence for this eruptive behavior has been previously recognized in the tuffisite structures of Panum Dome [Black et al. 2016], which nonetheless link that eruption to hybrid activity. At BGM, the close spatial association of coherent (effusive) and pyroclastic deposits suggest that explosive and effusive activity were closely overlapping in space and time. In this discussion we link salient field depositional relations and structures at BGM to possible eruption modes and evolution thereof.

Early in the eruption, one or more active tephra cones vented pyroclastic material, producing thick, overlapping airfall deposits (Figure 7; C. Dan Miller [personal communication 2005]). Given clear contact depositional relations, these vents were in close proximity to, and likely sourced, the voluminous obsidian lava flow as it effused. This interpretation corroborates previous work [Anderson 1933; Eichelberger 1975] indicating that the BGM lava flow was emitted from three separate vents, along an $\sim 1.5 \mathrm{~km} \mathrm{NNW}$-trending fissure, each erupting at different initial stages, but also simultaneously later in the eruption (Figure 7). In such a multivent eruption scenario, the conditions for pyroclast deposition on co-eruptive flows would have been met [e.g. Lara et al. 2004]. Indeed, the presence of pyroclastic deposits laying conformably atop BGM lava (Figure 3; Supplementary Material) speaks to this, and indicates that pyroclastic venting had not stopped when effusion started.

Further evidence for simultaneous explosive-effusive activity is provided by numerous pyroclastic ridges positioned within the flow, and not at the flow's margins (Figure 1). Pyroclastic deposits positioned at the flow's edge-were they to exist-would imply a sharp, unidirectional explosive-to-effusive eruption sequence. However, we have found no flow-bounding pyroclastic ridges, making this scenario implausible in light of the actual positioning of pristine lavas outboard of the pyroclastic units, particularly in the SW flow (Figure 1). Thus, the observed arrangement of lava $\rightarrow$ breccia ridge $\rightarrow$ lava (Figure 1) found in the SW flow requires that some of the lava was firstly emplaced unhindered to the SW before the inboard pyroclastic unitsat the time comprising actively venting cones-were rafted away. Later, as the pyroclastic cones were disrupted by lava sourced from different vents and transported, the breccia deposits became buttressed by both the early and later-erupted lava (Figure 7). The lava that rafted the pyroclasts would have been sourced from a different vent than the SW cone and accordingly must have been somewhere to the north along the fissure (Figure 7). That the form of the ridges is conformable with the large scale flow ridges indicates significant deformation of the pyroclastic cones and that integration of the pyroclasts in lava must have occurred well before the flow reached its final position.

Collectively, the formation of both the flow-top pyroclastic mantles and internal pyroclastic ridges require initial unhindered lava effusion from a actively venting pyroclastic cone or cones (Figure 7). Simultaneous eruption of lava away from the pyroclastic source would allow the first unhindered lava to come to rest without significant impediment of earlier built pyroclastic cones. We therefore envision at least early emission of lava from multiple horseshoe-shaped cones whereby lava could flow out from one side of the structure, as was observed at Cordón Caulle in 2011 [Castro et al. 2014, Supplementary Material].

\subsection{Degassing during pyroclastic and effusive activ- ity: the $\mathrm{H}$-isotopic record}

Hydrous geochemical measurements comprising $\delta \mathrm{D}$ and bulk $\mathrm{H}_{2} \mathrm{O}$ content on eruption products provide clues into the mechanism(s) of degassing that drove the most recent explosive and effusive activity at BGM [e.g. Eichelberger and Westrich 1981; Newman et al. 1988; Taylor 1991; Rust et al. 2004; Giachetti et al. 2020]. The data from this system-like those observed in other young rhyolite systems-shows an initial slight decline in $\delta \mathrm{D}$ over an extensive drop in $\mathrm{H}_{2} \mathrm{O}$ from high low values, followed by a sharp drop in $\delta \mathrm{D}$ in the low $-\mathrm{H}_{2} \mathrm{O}$ content realm (Figures 5 and 6). This geochemical pattern reflects an enhancement in fractionation of deuterium into the vapor phase, which is strengthened in the latest stages by both the shift in hydrous speciation (to more OH-rich composition) and consequent change of the melt vapor fractionation factor [e.g. Walter and Castro 2020]. Typically, the sharp drop in $\delta D$ is attributed to late-staged opening of the system to gas loss [e.g. Newman et al. 1988].

As we showed in Section 4.3, batched degassing, involving an initial large closed-system step followed by repetitive and progressively smaller batched-system steps [e.g. Taylor 1991, Figure 6] provided the best fit to natural $\delta \mathrm{D}-\mathrm{H}_{2} \mathrm{O}$ data. This good fit suggests that a repetitive degassing mechanism involving numerous outgassing pulses was important following what may have been an initial purely explosive Plinian stage at Big Glass Mountain.

Batched degassing behavior as described above was also identified in the $\delta \mathrm{D}-\mathrm{H}_{2} \mathrm{O}$ data of pyroclasts and lavas from Chaitén, and linked to the action of tuffisites during its 2008 hybrid eruption [Castro et al. 2014]. This recently active system provides a working model for how BGM's $\delta \mathrm{D}-\mathrm{H}_{2} \mathrm{O}$ data may have arisen from physical eruption processes. In particular, the ballisticbomb hosted tuffisite veins at Chaitén were found to alternately act as mass conservative and mass liberat- 
A

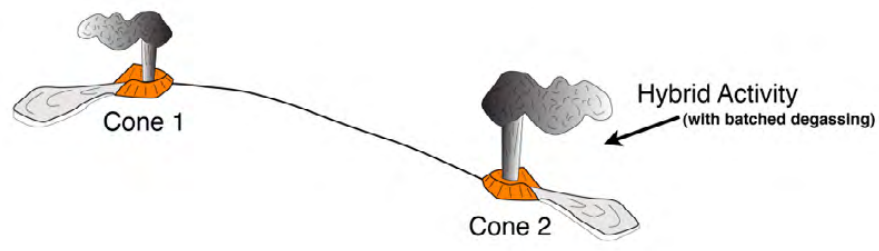

B
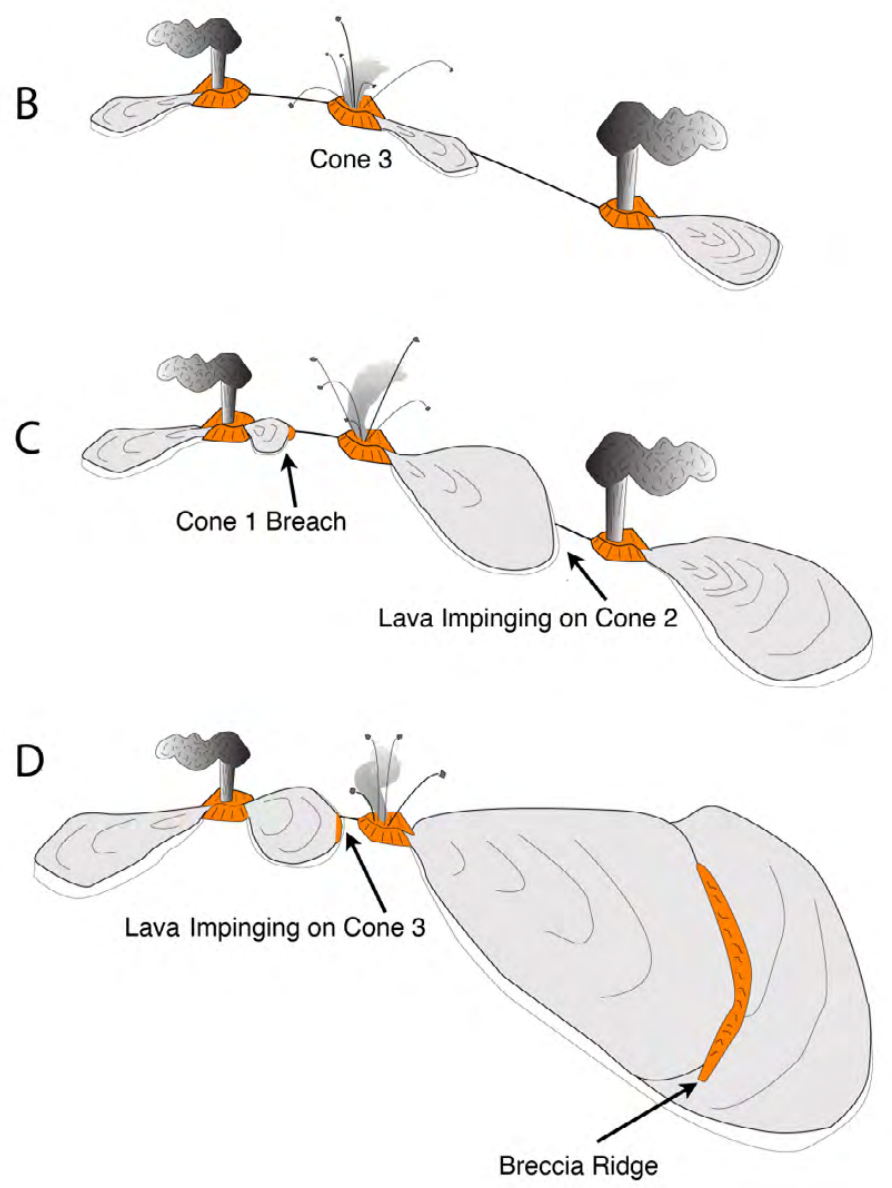

Figure 7: Schematic showing possible eruptive events leading to the formation of juxtaposed explosive and effusive deposits at Big Glass Mountain. Multiple eruptive vents were aligned along a NNW trending fissure (bold diagonal line), as shown in this perspective view from the southwest [see also Chesterman 1955; Eichelberger 1975]. [A] Initial pyroclastic eruptions occurred from northern and southernmost vents (Cones 1 and 2) along the main fissure [Eichelberger 1975]. [B]-[C] A third, middle vent (Cone 3) probably formed later, and may have been initially explosively active with later synchronous hybrid venting with the other two vents [Eichelberger 1975]. [D] The advancing lava from the Cone 3 vent would have eventually destroyed the southern most pyroclastic cone leading to its entrapment in the lava the observed pattern of Lava-Breccia RidgeLava on the SW flow front. Lava emitted from Cone 1 could have also breached its southern wall, leading to impingement of this flow on Cone 3 (Frame [D]), ultimately causing the destruction and rafting of Cone 3 and incorporation as a breccia ridge into the final flow field. The intense welding, vesiculation, and deformation of pyroclasts within the breccia zones (Figure 4) shows that little time passed between pyroclastic venting and subsequent disruption and rafting of cones by lava. ing systems, both storing pyroclasts and gas for short periods (10s of minutes) and then explosively releasing them (c.f. Figure 7 in Castro et al. [2014]). In this sense, Chaitén's tuffisites behaved like valves, enabling "batched" degassing cycles comprising closedsystem filling (e.g. via vesiculation and gas percolation into a crack) and explosive draining of volatile "aliquots". All the while that tuffisites were active, lava poured out from the same vent, its own degassed state an outcome of vigorous pyroclastic degassing through tuffisites. The outcome of this physical behavior is manifested in Chaitén's H-isotopic array, which shows clear geochemical continuity between early Plinian pyroclasts and later erupted lava [Castro et al. 2014, Figure 5].

It is also important to note that the pyroclastic fill in some of Chaitén's tuffisites [Castro et al. 2012; 2014] comprising densely sintered ash and obsidian lapilliexhibits markedly heavier $\mathrm{H}$-isotopic signatures than the dense obsidian hosts that contain them. Castro et al. [2014] interpreted this as evidence that tuffisite veins accessed deep portions of the conduit where they tapped into more primitive, deuterium-rich gas and pyroclasts, before conveying them to the surface and leading to some local pyroclast and lava buffering [e.g. Rust et al. 2004]. Tuffisites are, in this context and somewhat paradoxically, the physical hallmarks of "opensystem" behavior-the deep conveyance of material reflects this-but at the same time, such pyroclastic material lacks the classical geochemical signature of opensystem degassing, that is, the extreme deuterium depletion stemming from Rayleigh fractionation. Unlike $\delta \mathrm{D}$-depleted obsidian lavas from Chaitén, the previously described tuffisites remain $\delta \mathrm{D}$-enriched despite being relatively poor in $\mathrm{H}_{2} \mathrm{O}$. Thus, owing to these complexities, which collectively demonstrate that tuffisite structures may cycle through various different degassing modes (e.g. closed, batched, open, buffered; see Figure 7 in Castro et al. [2014]), a simple two-stage, unidirectional shift in degassing mode (e.g. closed-toopen) does not sufficiently explain Chaitén's hydrous geochemical array while also remaining consistent with 
the physical eruption events causing that data array.

We view the remarkable similarity in $\delta \mathrm{D}-\mathrm{H}_{2} \mathrm{O}$ systematics between eruption products from BGM and Chaitén (Figure 5), along with field relations pointing towards hybrid activity at BGM (e.g. breccia ridges), as strong evidence that the eruptive underpinnings of the degassing history at BGM were similar to those at Chaitén. While we have yet to find and analyze tuffisites from BGM, we contend that the conduit(s) at BGM could very well have undergone periods of shifting degassing mode as its degree of openness changed during hybrid activity. In other words, the conduits at BGM, acting like scaled-up tuffisites, would have experienced episodes of gas and pyroclast storage and transmittance, all of which could have been governed by fine-scale conduit processes involving cycles of fragmentation and re-healing of material [e.g. Schipper et al. 2013; Wadsworth et al. 2018; Kolzenburg et al. 2019; Schipper et al. 2021]. Indeed, Schipper et al. [2021] showed that brecciated rhyolite bombs repeatedly cast from the conduit at Cordón Caulle behaved like "supersized" tuffisites. The internal structures of these bombs indicate alternating modes of vesiculation, fragmentation, and sintering that led to densification of degassed magma that was in turn periodically forcefully ejected from the conduit during hybrid explosive-effusive activity [Castro et al. 2016].

Finally, it is also important to note that a two-staged, closed-to-open-system model also fits the data rather well (Figure 6C). Despite similar goodness of fit to natural data, this closed-to-open model is physically different than the batched-system model in that it requires a sharp unidirectional change in degassing and eruption mechanism, something that is not consistent with previously described field relations, degassing mechanisms and requisite geochemical patterns, or observations of active systems [e.g. Castro et al. 2013]. Future work should aim to sample and measure the hydrous signatures of bomb-hosted tuffisites at BGM to confirm the proposed geochemical and physical eruptive parallels between this and other active rhyolite systems. We recognize however that a geochemical dataset alone (i.e. in the absence physical eruption deposit evidence and/or real-time eruption observations) cannot implicate a particular eruption style or sequence.

5.3 Divining eruptive activity from hydrous geochemical trends and field relations

In terms of how the eruption may have physically transpired, the batched-degassing path is consistent with both an early purely explosive phase of activity (closedsystem degassing) —as evidenced by thick pumice fall deposits-and later hybrid eruptive behavior, involving repetitive blast and simultaneous lava effusion activity [e.g. Schipper et al. 2013; Castro et al. 2014]. The initial closed-system, and effectively large degassing amounts that mark the beginning of the sequence, could have come about from initial magma rise and attendant volatile exsolution into closed bubbles that remained in contact with the melt. The start of the eruption (the Plinian phase) would therefore have marked a massive closed-system, explosive release of these early exsolved volatiles. This interpretation has been validated by historically active subaerial rhyolites where the degassing pattern and eruption mechanism were found to be consistent across a wide range of samples (Chaitén and Cordón Caulle; e.g. Castro et al. [2014]). Most importantly, instead of sharply distinct degassing and eruption mechanisms-closed first then open, and first explosive then effusive- the Chilean eruptions exhibited pulsed, batched degassing, with explosive outbursts declining in intensity during prolonged effusive activity [Schipper et al. 2013].

On the whole, our hydrous geochemical data provide evidence of the nature of degassing that accompanied hybrid volcanism during the most recent explosiveeffusive eruption of BGM. This geochemical evidence points to a repetitive degassing process that physically coincides with distinctive, intercalated effusive and explosive deposits. This geochemical and physical evidence places the BGM eruption squarely in the behavioral class of Chaitén and Cordón Caulle eruptions. Thus, as concerns potential future rhyolite eruptions and hazards either at Medicine Lake or other potentially active systems, we would envision extensive hybrid activity with month-long periods of ash production alongside effusive activity and extensive pyroclastic flows [e.g. Schipper et al. 2013].

\section{Conclusions}

Detailed analyses of field relations, microtextures and hydrous geochemical signatures preserved in pyroclastic and effusive obsidians at BGM suggest that the most recent BGM eruption followed an hybrid eruptive course, one very much like the recent rhyolite events at Chaitén and Cordón Caulle. There was not likely a sharp shift in activity from explosive to effusive behavior, but rather a gradual shift from early intense Plinian explosions to long, drawn-out repetitive explosive venting accompanied by lava effusion. That the effusive lavas are so voluminous suggests that BGM would been explosively active for a very long time, perhaps months to years. Such activity would have produced ash clouds while the voluminous obsidian flow was emplaced [e.g. Black et al. 2016; Forte and Castro 2019]. Clearly, were such persistent ash venting and lava effusion to happen again today, this would present a most critical threat to air traffic, the local farming economy and regional volcanic threat [Forte et al. 2018].

Our work on BGM adds to the growing evidence that effusive rhyolitic volcanism is inextricably linked to explosive eruption [e.g. Black et al. 2016] and thusly calls for reassessment of prior models involving temporally abrupt change-overs in activity linked to thresh- 
olds in magmatic properties, such as bulk permeability [e.g. Eichelberger et al. 1986; Newman et al. 1988; Giachetti et al. 2020]. New models that incorporate cycles of volatile exsolution, melt fracturing, explosive outburst and release, followed by re-sintering of fragmental magma will contribute to better hazard assessments of the impacts of rhyolite events [Schipper et al. 2021].

\section{ACKnOWledgements}

The authors would like to thank Benjamin A. Black, Juliet Ryan-Davis, and Kayla Iacovino (editor) for insightful comments that helped improve the quality of this work. Jens Fiebeg provided essential analytical support while Nick Joslin and Brian Olmsted made fieldwork tractable and fun. We thank the University of Mainz's VAMOS research center for support of laboratory and analytical costs.

\section{Author contributions}

Both authors contributed equally to this study.

\section{Data AVailability}

All data in this manuscript are available as Supplementary Material alongside this article.

\section{Copyright NOTICE}

(C) The Author(s) 2021. This article is distributed under the terms of the Creative Commons Attribution 4.0 International License, which permits unrestricted use, distribution, and reproduction in any medium, provided you give appropriate credit to the original author(s) and the source, provide a link to the Creative Commons license, and indicate if changes were made.

\section{REFERENCES}

Alfano, F., C. Bonadonna, A. C. M. Volentik, C. B. Connor, S. F. L. Watt, D. M. Pyle, and L. J. Connor (2011). "Tephra stratigraphy and eruptive volume of the May, 2008, Chaitén eruption, Chile". Bulletin of Volcanology 73 (5), pp. 613-630. Dor: 10.1007 / s $00445-010-0428-\mathrm{x}$.

Anderson, C. A. (1933). "Volcanic history of glass mountain, Northern California". American Journal of Science 5 (155), pp. 485-506.

Anovitz, L. M., J. M. Elam, L. R. Riciputi, and D. R. Cole (2004). "Isothermal Time-Series Determination of the Rate of Diffusion of Water in Pachuca Obsidian". Archaeometry 46 (2), pp. 301-326. DoI: 10.1111/ j.1475-4754.2004.00159.x.

Bindeman, I., V. Kamenetsky, J. Palandri, and T. Vennemann (2012). "Hydrogen and oxygen isotope behaviors during variable degrees of upper mantle melting: Example from the basaltic glasses from Macquarie Is- land". Chemical Geology 310-311, pp. 126-136. Dor: $10.1016 / \mathrm{j}$. chemgeo 2012.03 .031$.

Black, B. A., M. Manga, and B. Andrews (2016). "Ash production and dispersal from sustained lowintensity Mono-Inyo eruptions". Bulletin of Volcanology 78 (8). DOI: $10.1007 / \mathrm{s} 00445-016-1053-0$.

Cabrera, A., R. F. Weinberg, and H. M. Wright (2015). "Magma fracturing and degassing associated with obsidian formation: The explosive-effusive transition". Journal of Volcanology and Geothermal Research 298, pp. 71-84. DoI: $10.1016 / \mathrm{j}$. jvolgeores . 2014. 12.014 .

Castro, J. M., I. N. Bindeman, H. Tuffen, and C. I. Schipper (2014). "Explosive origin of silicic lava: Textural and $\delta \mathrm{D}-\mathrm{H}_{2} \mathrm{O}$ evidence for pyroclastic degassing during rhyolite effusion". Earth and Planetary Science Letters 405, pp. 52-61. Dor: 10.1016/j . epsl.2014.08. 012.

Castro, J. M., B. Cordonnier, C. I. Schipper, H. Tuffen, T. S. Baumann, and Y. Feisel (2016). "Rapid laccolith intrusion driven by explosive volcanic eruption". $\mathrm{Na}$ ture Communications 7 (1). DoI: 10.1038/ncomms 13585. Castro, J. M., B. Cordonnier, H. Tuffen, M. J. Tobin, L. Puskar, M. C. Martin, and H. A. Bechtel (2012). "The role of melt-fracture degassing in defusing explosive rhyolite eruptions at volcán Chaitén". Earth and Planetary Science Letters 333-334, pp. 63-69. Dor: 10.1016/j.eps1.2012.04.024.

Castro, J. M. and D. B. Dingwell (2009). "Rapid ascent of rhyolitic magma at Chaitén volcano, Chile". Nature 461 (7265), pp. 780-783. DOI: $10.1038 /$ nature08458.

Castro, J. M., D. B. Dingwell, A. R. Nichols, and J. E. Gardner (2005a). "New insights on the origin of flow bands in obsidian". Kinematics and dynamics of lava flows. Ed. by M. Manga and G. Ventura. Geological Society of America. ISBN: 9780813723969. DOI: 10 . 1130/0-8137-2396-5.55. GSA Special Papers.

Castro, J. M. and J. E. Gardner (2008). "Did magma ascent rate control the explosive-effusive transition at the Inyo volcanic chain, California". Geology 36 (4), p. 279. DoI: 10.1130/g24453a.1.

Castro, J. M., F. Keller, Y. Feisel, P. Lanari, C. Helo, S. P. Mueller, C. I. Schipper, and C. Thomas (2020). "Lightning-induced weathering of Cascadian volcanic peaks". Earth and Planetary Science Letters 552, p. 116595. Dor: 10.1016/j.eps1.2020.116595.

Castro, J. M., M. Manga, and M. C. Martin (2005b). "Vesiculation rates of obsidian domes inferred from $\mathrm{H}_{2} \mathrm{O}$ concentration profiles". Geophysical Research Letters 32 (21). DoI: 10.1029/2005gl024029.

Castro, J. M. and C. Mercer (2004). "Microlite textures and volatile contents of obsidian from the Inyo volcanic chain, California". Geophysical Research Letters 31 (18). DOI: 10.1029/2004gl020489.

Castro, J. M., C. I. Schipper, S. P. Mueller, A. S. Militzer, A. Amigo, C. S. Parejas, and D. Jacob (2013). "Storage and eruption of near-liquidus rhyolite magma at 
Cordón Caulle, Chile”. Bulletin of Volcanology 75 (4). Dor: $10.1007 / \mathrm{s} 00445-013-0702-9$.

Chesterman, C. W. (1955). "Age of the Obsidian Flow at Glass Mountain, Siskiyou County, California”. American Journal of Science 253 (7), pp. 418-424.

DeGroat-Nelson, P. J., B. Cameron, J. Fink, and J. Holloway (2001). "Hydrogen isotope analysis of rehydrated silicic lavas: implications for eruption mechanisms". Earth and Planetary Science Letters 185 (3-4), pp. 331-341. Dor: 10.1016/s $0012-821 \mathrm{x}(00) 00379-4$.

Dobson, P. F., S. Epstein, and E. M. Stolper (1989). "Hydrogen isotope fractionation between coexisting vapor and silicate glasses and melts at low pressure". Geochimica et Cosmochimica Acta 53 (10), pp. 27232730. DoI: $10.1016 / 0016-7037$ (89)90143-9.

Donnelly-Nolan, J. M., D. E. Champion, and T. L. Grove (2016). Late Holocene volcanism at Medicine Lake Volcano, northern California Cascades. DoI: 10.3133/ pp1822. [Professional Paper 1822].

Donnelly-Nolan, J. M., T. L. Grove, M. A. Lanphere, D. E. Champion, and D. W. Ramsey (2008). "Eruptive history and tectonic setting of Medicine Lake Volcano, a large rear-arc volcano in the southern Cascades". Journal of Volcanology and Geothermal Research 177 (2), pp. 313-328. Dor: $10.1016 / j$. jvolgeores.2008.04.023.

Donnelly-Nolan, J. M., M. Nathenson, D. E. Champion, D. W. Ramsey, J. B. Lowenstern, and J. W. Ewert (2007). Volcano Hazards Assessment for Medicine Lake Volcano, Northern California. DoI: 10.3133/ sir20075174a. [Scientific Investigations Report 20075174-A].

Eichelberger, J. C., C. R. Carrigan, H. R. Westrich, and R. H. Price (1986). "Non-explosive silicic volcanism". Nature 323 (6089), pp. 598-602. DoI: 10.1038/ 323598a0.

Eichelberger, J. C. (1975). "Origin of andesite and dacite: Evidence of mixing at Glass Mountain in California and at other circum-Pacific volcanoes". Geological Society of America Bulletin 86 (10), p. 1381. Dor: $10.1130 / 0016-7606$ (1975) $86<1381$ : ooaade $>2.0$. co ; 2.

- (1995). "Silicic Volcanism: Ascent of Viscous Magmas from Crustal Reservoirs". Annual Review of Earth and Planetary Sciences 23 (1), pp. 41-63. Dor: 10.1146/ annurev.ea.23.050195.000353.

Eichelberger, J. C. and H. R. Westrich (1981). "Magmatic volatiles in explosive rhyolitic eruptions". Geophysical Research Letters 8 (7), pp. 757-760. Dor: 10 . 1029/gl008i007p00757.

Forte, P. B. (2019). "New insights into the characteristics and dynamics of rhyolite long-lasting volcanic eruptions". PhD thesis. Johannes Gutenberg University Mainz.

Forte, P. B. and J. M. Castro (2019). " $\mathrm{H}_{2} \mathrm{O}$-content and temperature limit the explosive potential of rhyolite magma during Plinian eruptions". Earth and Plane- tary Science Letters 506, pp. 157-167. DoI: 10.1016/ j.epsl.2018.10.041.

Forte, P. B., L. Domínguez, C. Bonadonna, C. E. Gregg, D. Bran, D. Bird, and J. M. Castro (2018). "Ash resuspension related to the 2011-2012 Cordón Caulle eruption, Chile, in a rural community of Patagonia, Argentina". Journal of Volcanology and Geothermal Research 350, pp. 18-32. DoI: $10.1016 / \mathrm{j}$. jvolgeores . 2017.11.021.

Giachetti, T., M. R. Hudak, T. Shea, I. N. Bindeman, and E. C. Hoxsie (2020). "D/H ratios and $\mathrm{H}_{2} \mathrm{O}$ contents record degassing and rehydration history of rhyolitic magma and pyroclasts". Earth and Planetary Science Letters 530, p. 115909. DoI: 10.1016/ j . epsl . 2019. 115909.

Gonnermann, H. M. and M. Manga (2003). "Explosive volcanism may not be an inevitable consequence of magma fragmentation". Nature 426 (6965), pp. 432435. DoI: $10.1038 /$ nature 02138 .

- (2007). "The Fluid Mechanics Inside a Volcano". Annual Review of Fluid Mechanics 39 (1), pp. 321-356. DoI: 10.1146/annurev . fluid. 39.050905.110207.

Heap, M. J., H. Tuffen, F. B. Wadsworth, T. Reuschlé, J. M. Castro, and C. I. Schipper (2019). "The Permeability Evolution of Tuffisites and Implications for Outgassing Through Dense Rhyolitic Magma". Journal of Geophysical Research: Solid Earth 124 (8), pp. 8281-8299. Dor: 10.1029/2018jb017035.

Heiken, G. (1978). "Plinian-type eruptions in the medicine lake highland, california, and the nature of the underlying magma". Journal of Volcanology and Geothermal Research 4 (3-4), pp. 375-402. DOI: 10 . 1016/0377-0273(78)90023-9.

Ihinger, P. D., R. L. Hervig, and P. F. McMillan (1994). "Analytical methods for volatiles in glasses". Reviews in Mineralogy and Geochemistry 30 (1), pp. 67-122.

Jaupart, C. and C. J. Allègre (1991). "Gas content, eruption rate and instabilities of eruption regime in silicic volcanoes". Earth and Planetary Science Letters 102 (34), pp. 413-429. DoI: 10.1016/0012-821x(91) 90032d.

Katsui, Y. and H. R. Katz (1967). "Lateral fissure eruptions in the southern Andes of Chile". Journal of the Faculty of Science, Hokkaido University 13 (4), 433s448.

Kolzenburg, S., A. Ryan, and J. Russell (2019). "Permeability evolution during non-isothermal compaction in volcanic conduits and tuffisite veins: Implications for pressure monitoring of volcanic edifices". Earth and Planetary Science Letters 527, p. 115783. Dor: 10. 1016/j .epsl.2019.115783.

Lange, R. L. and I. S. E. Carmichael (1990). "Thermodynamic properties of silicate liquids with emphasis on density, thermal expansion and compressibility". Reviews in Mineralogy and Geochemistry 24 (1), pp. 2564. 
Lara, L. E. (2009). "La erupcion 2008 del volcan Chaiten, Chile: informe preliminar." Andean Geology 36 (1). Dor: 10.5027 /andgeov36n1-a09.

Lara, L. E., J. A. Naranjo, and H. Moreno (2004). "Rhyodacitic fissure eruption in Southern Andes (Cordón Caulle 40.5 $\mathrm{S}$ ) after the 1960 (Mw:9.5) Chilean earthquake: a structural interpretation". Journal of Volcanology and Geothermal Research 138 (1-2), pp. 127138. Dor: $10.1016 / \mathrm{j}$. jvolgeores . 2004.06.009.

Miller, C. D. (1985). "Holocene eruptions at the Inyo volcanic chain, California: Implications for possible eruptions in Long Valley caldera". Geology 13 (1), p. 14 . DoI: $10.1130 / 0091-7613$ (1985) $13<14$ : heativ $>$ 2.0.co;2.

Newman, S., S. Epstein, and E. Stolper (1988). "Water, carbon dioxide, and hydrogen isotopes in glasses from the ca. 1340 A.D. eruption of the Mono Craters, California: Constraints on degassing phenomena and initial volatile content". Journal of Volcanology and Geothermal Research 35 (1-2), pp. 75-96. DOI: 10 . 1016/0377-0273(88)90007-8.

Nolan, G. S. and I. N. Bindeman (2013). "Experimental investigation of rates and mechanisms of isotope exchange $(\mathrm{O}, \mathrm{H})$ between volcanic ash and isotopicallylabeled water". Geochimica et Cosmochimica Acta 111, pp. 5-27. Dor: 10.1016/j.gca.2013.01.020.

Pallister, J., A. K. Diefenbach, W. C. Burton, J. Muñoz, J. P. Griswold, L. E. Lara, J. B. Lowenstern, and C. E. Valenzuela (2013). "The Chaitén rhyolite lava dome: Eruption sequence, lava dome volumes, rapid effusion rates and source of the rhyolite magma". Andean Geology 40 (2). DOI: $10.5027 /$ andgeov40n2-a@6.

Rust, A., K. Cashman, and P. Wallace (2004). "Magma degassing buffered by vapor flow through brecciated conduit margins". Geology 32 (4), p. 349. DoI: 10 . $1130 / g 20388.2$.

Saubin, E., H. Tuffen, L. Gurioli, J. Owen, J. M. Castro, K. Berlo, E. M. McGowan, C. I. Schipper, and K. Wehbe (2016). "Conduit Dynamics in Transitional Rhyolitic Activity Recorded by Tuffisite Vein Textures from the 2008-2009 Chaitén Eruption". Frontiers in Earth Science 4. DoI: 10.3389/feart.2016.00059.

Schipper, C. I., J. M. Castro, B. M. Kennedy, H. Tuffen, J. Whattam, F. B. Wadsworth, R. Paisley, R. H. Fitzgerald, E. Rhodes, L. N. Schaefer, P. A. Ashwell, P. Forte, G. Seropian, and B. V. Alloway (2021). "Silicic conduits as supersized tuffisites: Clastogenic influences on shifting eruption styles at Cordón Caulle volcano (Chile)". Bulletin of Volcanology 83 (2). Dor: 10.1007/ s $00445-020-01432-1$.

Schipper, C. I., J. M. Castro, H. Tuffen, M. R. James, and P. How (2013). "Shallow vent architecture during hybrid explosive-effusive activity at Cordón Caulle (Chile, 2011-12): Evidence from direct observations and pyroclast textures". Journal of Volcanology and Geothermal Research 262, pp. 25-37. Dor: 10.1016/j . jvolgeores.2013.06.005.

Scott, W. E. (1987). "Holocene rhyodacite eruptions on the flanks of South Sister volcano, Oregon". The Em- placement of Silicic Domes and Lava Flows. Ed. by J. H. Fink. Vol. 212. Geological Society of America, pp. 35-54. ISBN: 9780813722122. DOI: 10.1130/ spe212-p35. [GSA Special Papers].

Taylor, B. E., J. C. Eichelberger, and H. R. Westrich (1983). "Hydrogen isotopic evidence of rhyolitic magma degassing during shallow intrusion and eruption". Nature 306 (5943), pp. 541-545. Dor: 10 . 1038/306541a@.

Taylor, B. E. (1991). "Degassing of obsidian dome rhyolite, Inyo volcanic chain, California". Stable isotope geochemistry: A tribute to Samuel Epstein. Ed. by H. P. Taylor Jr., J. R. O’Neil, and I. R. Kaplan. Geological Survey of Canada, pp. 339-353.

Tuffen, H., D. B. Dingwell, and H. Pinkerton (2003). "Repeated fracture and healing of silicic magma generate flow banding and earthquakes?" Geology 31 (12), p. 1089. DoI: 10.1130/g19777.1.

Tuffen, H., M. R. James, J. M. Castro, and C. I. Schipper (2013). "Exceptional mobility of an advancing rhyolitic obsidian flow at Cordón Caulle volcano in Chile". Nature Communications 4 (1). DoI: 10.1038/ ncomms 3709 .

Wadsworth, F. B., T. Witcher, C. E. J. Vossen, K.-U. Hess, H. E. Unwin, B. Scheu, J. M. Castro, and D. B. Dingwell (2018). "Combined effusive-explosive silicic volcanism straddles the multiphase viscous-tobrittle transition". Nature Communications 9 (1). Dor: $10.1038 / \mathrm{s} 41467-018-07187-\mathrm{W}$.

Walter, S. (2017). "Simulation of degassing and isotope fractionation of hydrogen in rhyolitic melts: A study of Big Glass Mountain, Ca”. MA thesis. Johannes Gutenberg University, Mainz.

Walter, S. and J. M. Castro (2020). "VolcDeGas: A program for modelling hydrogen isotope fractionation during degassing of rhyolitic melts". Volcanica 3 (1), pp. 155-168. DoI: 10.30909/vol.03.01.155168.

Waters, L. E., B. J. Andrews, and R. A. Lange (2015). "Rapid Crystallization of Plagioclase Phenocrysts in Silicic Melts during Fluid-saturated Ascent: Phase Equilibrium and Decompression Experiments". Journal of Petrology 56 (5), pp. 981-1006. DoI: 10.1093/ petrology/egve25.

Waters, L. E. and R. A. Lange (2016). "No effect of $\mathrm{H}_{2} \mathrm{O}$ degassing on the oxidation state of magmatic liquids". Earth and Planetary Science Letters 447, pp. 4859. DoI: $10.1016 /$ j.epsl.2016.04.030.

Watt, S. F. L., D. M. Pyle, T. A. Mather, R. S. Martin, and N. E. Matthews (2009). "Fallout and distribution of volcanic ash over Argentina following the May 2008 explosive eruption of Chaitén, Chile". Geophysical Research Letters 114 (B4). DoI: 10. 1029/2008jb006219. Woods, A. W. and T. Koyaguchi (1994). "Transitions between explosive and effusive eruptions of silicic magmas". Nature 370 (6491), pp. 641-644. Dor: 10.1038/ $370641 \mathrm{a} 0$. 